\title{
Mamki - najemne karmicielki w świetle literatury poradnikowej z drugiej połowy XIX i początku XX wieku
}

\begin{abstract}
Wet nurses - hired breast-feeders in the light of the "how-to" literature from the second half of the 19th and early 20th centuries

Wet nurses, i.e. hired breast-feeders of babies, were the subject matter of this research. It aims to systematize the advice that was formulated on the pages of "how-to" books regarding the search for, recruitment, and treatment of wet nurses in the homes of one's charges. The specific duties of wet nurses that were especially expected of them are determined, as well as the errors most frequently committed in their performance, which the authors of how-to books described at length, in order to warn mothers against the incompetence of paid breast-feeders. A comparison of the views of authors of "how-to" books over nearly 70 years will allow us to determine a possible evolution of views regarding wet nursing.

The "how-to" books on health, hygiene, and education from the second half of the 19th century and the early 20th century (the period approximately from 1850-1918), published in Polish areas and addressed mainly at families, especially mothers, form the source material for the research. The use of this type of literature will allow us to reconstruct the promulgated image of wet nursing without broader reference to providing help for them, which is worth confronting with the "how-to" recommendations, attempting to determine whether, and to what extent, they were reflected in everyday life (e.g. using epistolary or archival sources, and memoirs). Nevertheless, the authors of "how-to" books also referred to the practice of tending infants and young children, criticizing inappropriate behaviour of wet nurses, while the recommendations formulated by them were to remedy inappropriate behaviour occurring in reality.

The issue of wet nursing has not hitherto been analysed in detail in Polish historiography. In recent years, though, a few texts or papers in which one can find more or less extensive information (the less extensive ones predominate) related to breastfeeding by wet nurses in the Polish areas in the Middle Ages, the period of Old Poland, or the partition period, have been published. Thus, it seems even more reasonable to explore this issue, which will help to fill a gap in the development of the history of breastfeeding, nursing, and tending infants and small children.
\end{abstract}

Keywords: wet nurse, breastfeeding, "how-to" book, tending children, nursing 
Sa okolice i sfery towarzyskie, które bez mamki ani rusz obejść się nie umieja. Mamka zostać, to nieprzebrane źródto dochodu dla ubogich kobiet z ludu, a panie zamożne klas wyższych nie pojmuja wcale, jak można obejść się bez mamki mając dzieci [...] Jedna matka staje się wiarołomną względem swojego niebożątka, ażeby się oddać obcemu dziecku, inna matka zdaje swe obowiazki macierzyńskie, które powinny być dla niej święte, obcej kobiecie, ażeby się bawić! Cóż za spaczenie przyrodzonych stosunków! surowo oceniała obyczaj zatrudniania mamek w początku XX w. autorka jednego z popularnych poradników z zakresu higieny i lecznictwa ${ }^{1}$. Przedmiotem niniejszych badań uczyniono mamki, najemne karmicielki niemowląt. Celem dokonanych ustaleń jest próba systematyki wskazówek i porad, jakie formułowano na stronach poradników w zakresie poszukiwania, zatrudniania i traktowania mamek w domach swoich podopiecznych. Określone zostaną postulowane obowiązki mamek, a także najczęściej popełnianie błędy w ich wypełnianiu, jakie autorzy poradników szeroko opisywali, chcąc przestrzec matki przed niekompetencją płatnych karmicielek. Porównanie poglądów autorów poradników na przestrzeni niemal siedemdziesięciu lat pozwoli stwierdzić ewentualną ewolucję poglądów na mamczarstwo.

Podstawą źródłową badań uczyniono poradniki z zakresu zdrowia, higieny i wychowania z drugiej połowy wieku XIX i początku wieku XX (za umowne cezury czasowe przyjęto lata ok. 1850-1918), opublikowane na terenie ziem polskich, adresowane w głównej mierze do rodzin, a szczególnie do matek. Wykorzystanie tego typu literatury pozwoli odtworzyć postulowany obraz mamczarstwa, bez szerszego odniesienia do rzeczywistości, którą warto skonfrontować z poradnikowymi zaleceniami, próbując stwierdzić, czy i w jakim stopniu miały one swe odzwierciedlenie w codziennym życiu (np. z wykorzystaniem źródeł pamiętnikarskich, epistolograficznych, archiwalnych). Niemniej autorzy poradników także odwoływali się do praktyki opieki nad niemowlętami i małymi dziećmi, krytykując niewłaściwe zachowania mamek, a formułowane przez nich porady miały na celu naprawę niewłaściwych zachowań mających miejsce w rzeczywistości.

W historiografii polskiej problematyka mamczarstwa nie jest dokładnie rozpoznana. W ostatnich latach ukazały się nieliczne teksty czy prace, w których można znaleźć bardziej lub mniej obszerne (i te dominują) informacje poświęcone karmieniu piersią przez mamki na terenach ziem polskich w czasach średniowiecza, w okresie staropolskim czy doby zaborów² ${ }^{2}$ Tym bardziej zasadne wydaje się eksplorowanie tej tematyki przez bada-

Dr A. Fischer-Dueckelmann, Kobieta lekarka domową: podręcznik lekarski do pielęgnowania zdrowia i lecznictwa $w$ rodzinie, ze szczególnym uwzględnieniem chorób kobiecych i dziecięcych, położnictwa i pielęgnowania dzieci, na pol. przeł. za zezw. aut. Teresa Jaroszewska z współudz. A. Czarnowskiego, Mikołów Warszawa 1908, s. 738.

${ }^{2}$ E. Kowecka, $W$ salonie $i$ w kuchni, Opowieść o kulturze materialnej pałaców i dworów polskich $w$ XIX w., wyd. III, Poznań 2008, s. 29; M. Delimata, Dziecko w Polsce średniowiecznej, Poznań 2004, s. 87-88; D. Żołądź-Strzelczyk, Dziecko w dawnej Polsce, wyd. II, Poznań 2006, s. 112-116; B. Ogrodowska, Polskie tradycje rodzinne, Warszawa 2007, s. 68; A. Bołdyrew, Matka i dziecko $w$ rodzinie polskiej. Ewolucja modelu życia rodzinnego w latach 1795-1918, Warszawa 2008, s. 71-75; A. Pachocka, Dzieciństwo we dworze szlacheckim w I połowie XIX wieku, Kraków 2009, s. 77-80; M. Stawiak-Ososińska, Ponętna, akuratna, uległa. Ideat $i$ wizerunek kobiety polskiej pierwszej połowy XIX wieku, (w świetle ówczesnych poradników), Kraków 2009, s. 265-268; M. Nawrot-Borowska, Najemni wychowawcy domowi w dzieci polskich w II połowie XIX poczatku 
czy, które pozwoli wypełnić lukę w zakresie opracowania dziejów karmienia piersią, pielęgnacji oraz opieki nad niemowlęciem i małym dzieckiem.

Jak wynika z przeprowadzonych analiz źródłowych, w stosunkowo wielu poradnikach badanego okresu, szczególnie tych adresowanych do kobiet, znajdujemy zalecenia dotyczące wyboru i powinności mamek. Jednak wskazówki w tym zakresie formułowano nie tylko na stronach poradników z zakresu zdrowia, higieny i lecznictwa (choć te zdecydowanie dominują), ale problematykę tę poruszano także na łamach książek pedagogicznych o charakterze poradnikowym, dotyczących opieki i wychowania dziecka, adresowanych do rodziców, a w szczególności do matek ${ }^{3}$.

Stosowanie się do wskazówek zawartych w poradnikach pozwalało uniknąć błędów i niepowodzeń w wielu dziedzinach życia. Wykorzystane tu poradniki higieniczne i wychowawcze miały za główny cel służenie pomocą najczęściej młodym i niedoświadczonym jeszcze matkom we właściwej opiece i pielęgnacji oraz wychowaniu dzieci. Pisane były najczęściej przez fachowców w danej dziedzinie, głównie lekarzy i higienistów, pedagogów, wykorzystujących wiedzę naukową i wieloletnie doświadczenie, dawały więc gwarancję skuteczności i z pewnością budziły społeczne zaufanie. Cześć była autorstwa rodzimych autorów, cześć stanowiły tłumaczenia naukowców zachodnich, głównie niemieckich, francuskich, często $\mathrm{z}$ adnotacjami i komentarzami thumaczy z dostosowaniem do specyfiki warunków terenu ziem polskich. W poradniku z połowy XIX w. czytamy: Cel tej książeczki jest pożytek, a nie wystawa. Wiele matek wyszukuje chciwie najlepsze sposoby prowadzenia dzieci: spodziewamy się, że następujące uwagi będa im pożyteczne [...] niniejsze pisemko zawiera bowiem tyle rad, przestróg, uwag, postrzė̇eń opartych na doświadczeniu, przydatnych matkom w każdo-dziennych przygodach z dzieć$m i^{4}$. Pięćdziesiąt lat później w poradniku adresowanym do kobiet wszystkich stanów autorka napisała: głównym zadaniem kobiety, którą Bóg dziećmi obdarza, jest ich należyte pielegnowanie $i$ wychowanie, podaję wiązanek rad $i$ wskazówek pod tym względem. Z nieświadomości bowiem matek wynikaja nie tylko straty pieniężne, lecz - co gorzejniepowetowane niczym choroby, a często i śmierć pierwszych dzieci, dopóki młoda matka jakiego takiego doświadczenia nie nabierze ${ }^{5}$. Podkreślić jednak należy, że dostępność do

XX wieku, w: O wychowawcach $i$ wychowaniu. Perspektywa myślenia pedagogicznego, red. E. Kubiak-Szymborska, Bydgoszcz 2010, s. 43-46; eadem, Wybór materiatów ikonograficznych z zakresu edukacji domowej dzieci polskich $w$ latach 1850-1914, w: Wychowanie - opieka - kształcenie. Z badań nad wybranymi problemami edukacji w XX i XXI wieku, red. M. Brodnicki, E. Gorloff, A. Kołakowski, Toruń 2010, s. 206-209; M. Krawczyński, T. Sioda, S. Silska, Mamka i jej rola $w$ ewolucji żywienia niemowląt, „Pediatria Polska” 2012, nr 10, s. 109-116 (część I), nr 2, s. 212-229 (część II i III).

${ }^{3}$ Analizie poddano ponad 180 poradników z zakresu zdrowia, higieny i lecznictwa, a także wychowania, publikowanych na terenie ziem polskich w badanym okresie, zdecydowana jednak większość z nich powstała na przełomie XIX i XX, a także w pierwszym dziesięcioleciu XX w. W 63 z analizowanych poradników znajdowały się istotne $\mathrm{z}$ punktu widzenia przedmiotu badań informacje, często ujęte $\mathrm{w}$ odrębne rozdziały poświęcone mamkom. 39 poradników pochodzi z zaboru rosyjskiego (zdecydowania większość opublikowana została w Warszawie), 17 z austriackiego (w większości opublikowane we Lwowie i Krakowie) i 7 z zaboru pruskiego (opublikowane w Poznaniu)

${ }^{4}$ Matka $w$ domu, tłum. z ang. przez A. G., Poznań 1847, s. 5-6.

5 Upominek dla matek i gospodyń, napisała Antoszka, Warszawa 1896, s. 4-5. 
tego typu porad była ograniczona do tych grup społecznych, które potrafiły czytać oraz mogły sobie pozwolić na zakup książek. W głównej mierze więc adresatami literatury poradnikowej byli ludzie pochodzący z warstw zamożnych - arystokratycznych, szlachecko-ziemiańskich, inteligenckich, mieszczańskich, rzadziej zaś robotniczych czy chłopskich.

Wskazując liczne błędy w opiece i pielęgnacji niemowląt i małych dzieci, w tym także zatrudniania mamek, Juliusz Payot na początku XX w. podkreślał znaczenie porad i wskazówek opartych na wiedzy medycznej i higienicznej, podnoszącej świadomość matek we wskazanym zakresie - Większość wiadomości, jakie maja kobiety o tych przepisach, o tych staraniach, jest oparta tylko na doświadczeniu, sa to tradycje zgubne [...] Tym gorzej dla maleństwa. Niepodobna dosięgnać wszystkich matek $i$ wykorzenić z ich umystu przestarzałych, fatszywych pojęć i niebezpiecznych nawyknień, lecz gdyby młode dziewczęta otrzymywały wskazówki, które im kiedyś będa nadzwyczaj potrzebne, w przyszłości zmniejszyłaby się w znacznej części zastraszająca śmiertelność niemowląt ${ }^{6}$. W poniższym tekście te właśnie wskazówki zostaną usystematyzowane problemowo i zaprezentowane.

W zasobach leksykalnych badanego okresu mamką określano karmicielkę i piastunkę dziecka. W 1857 r. w jednym ze słowników czytamy, że mamka to niewiasta nowo zległa, najęta za pewna cenę do karmienia dziecięcia cudzego ${ }^{7}$. W słownikach pojawiają się także takie wyrażenia, jak mamczenie - karmienie dziecięcia piersiami, nie będąc mu matka ${ }^{8}$, mamczyć - karmić cudze dziecię piersiami, mamka być, za mamke stużyć. W początku wieku XX definicje mamki zarówno słownikowe, jak i te zawarte w poradnikach nie uległy znaczącym zmianom, np. mamka określamy tę kobietę, która za wynagrodzeniem karmi obce dziecię zamiast własnego ${ }^{10}$ (1908); mamka - (karmicielka, żywicielka) - kobieta, karmiaca piersia cudze dziecko $(1916)^{11}$.

Autorzy poradników wychowawczych i higienicznych zgodnie stwierdzali, że naturalnym obowiązkiem matki jest karmienie dziecka piersią. W każdym z analizowanych poradników, w którym poruszano problematykę karmienia niemowląt, podkreślano wagę samodzielnego karmienia dziecka przez matkę ${ }^{12}$. Pierwszy pokarm dla niemowlęcia

${ }^{6}$ J. Payot, Wykład moralności, przekł. z franc. J. Warnkówna, Warszawa 1918, s. 46.

7 Stownik języka polskiego przez M. Samuela Linde, wyd. II, t. II (M-O), Lwów 1857, s. 38.

${ }^{8}$ Stownik języka polskiego, obejmujący oprócz zbioru właściwie polskich, znaczna liczbę wyrazów z obcych języków [...] do podręcznego użytku. Wypracowany przez A. Zdanowicza, M. Bohusza-Szyszkę, J. Filipowicza, W. Tomaszewicza, F. Czepielińskiego i W. Korotyńskiego, z udziałem B. Trentowskiego, cz. 1, A-O, Wilno 1861, s. 628 .

9 Ibidem.

${ }^{10}$ Dr A. Fischer-Dueckelmann, op. cit., s. 416.

11 M. Arcta, Słownik ilustrowany języka polskiego, t. III, Warszawa 1916, s. 701.

${ }^{12}$ Chowanna, czyli system pedagogiki narodowej jako umiejętności wychowania, nauki i oświaty stowem wykształcenia naszej młodzieży przez Bronisława Ferdynanda Trentowskiego, t. I, Poznań 1845, s. 368-369; Poradnik dla młodych matek w pierwszych siedmiu latach, napisat dr T. T. Matecki, praktyczny lekarz, chirurg i akuszer, Poznań 1848, s. 20, 38, 103, 166-167; Higiena polska, czyli sztuka zachowania zdrowia, przedtuzenia życia i uchronienia się od chorób zastosowana do użytku popularnego z szczególnym poglądem na okoliczności w naszym kraju i klimacie wptynąć mogące na tworzenie się stabości, cierpień i chorób przez T. Trippli- 
wskazała natura. Pierś matki nie da się w zupetności niczym zastapić. To też matka nie powinna uchylać się od tego obowiazku pod żadnym urojonym pozorem - pisał autor poradnika, uświadamiającego matkom najważniejsze fundamenty wychowania dziecka, za takiż uznając właśnie karmienie piersią ${ }^{13}$. Chcąc skłonić kobiety do samodzielnego karmienia piersią wskazywano na wiele pozytywów, które miało ono za sobą pociągać, a także negatywów, będących konsekwencją rezygnacji z tej czynności - zarówno dla matki, jak i dla dziecka. Argumentowano (szczególnie w środowisku lekarskim), że kobieta karmiąca, prędzej utraca i mniej oddziela czyszczenia połogowego niż ta, która

na, autora Pamiętników lekarza polskiego, Warszawa 1857, t. I, s. 33, 106-107; Rady dla matek, czyli sposób utrzymania kobiety od narodzenia do późnej starości, skreślił Julian Moszyński, doktor medycyny, Wilno 1858, s. 17; Wychowanie dziecka wedtug B. H. Gausserona, oprac. H. Michałowski, cz. I, Warszawa 1902, s. 13; Na czem opiera się wychowanie wedtug dr-a Buckiego, opracował J. Muklanowicz, Warszawa 1905, s. 11; Medycyna ludowa, czyli treściwy pogląd na środki ochronne, poznawanie i leczenie chorób. Poradnik lekarski dla wszystkich stanów według najnowszych źródel, skreślił dr med. A. Simon, Warszawa 1860, s. 84; Pedagogika polska w zarysie, skreślił Władysław Seredyński, Lwów 1868, s. 58-59; Jak zachować dziecko zdrowem? Poradnik dla młodych matek, skreślił dr med. O. Schmidt, tłum. dr J. St., Warszawa 1891, s. 20, 24; Dr med. L. Natanson, Higiena praktyczna, cześć II, Warszawa 1891, s. 139; Skrofuly (zołzy). Przyczyny, zapobieganie leczenie. Poradnik dla wszystkich napisał dr P. Niemeyer, thum. dr J. St., Warszawa 1889, s. 26; L. Weitzenblut, Szkic higieniczny: mężatka $i$ matka, czyli przepisy zachowania się dla kobiet $w$ stanie brzemiennym oraz pielęgnowania dzieci nowonarodzonych, Warszawa 1871, s. 87; A. Józefczyk, Listy pedagogiczne brata do siostry, Lwów 1880, s. 7; Szkice pedagogiczne, skreślił Ksawery Pałuczanin, Poznań 1881, s. 75; Dr E. Brucke, Jak ochraniać życie i zdrowie dzieci? przekł. z niem. M. Flauma, Warszawa 1892, s. 1; Dyjetetyka dzieci oparta na wskazówkach przyrody. Przewodnik $w$ zdrowem pielęgnowania dzieci od przyjścia na świat aż do dojrzenia skreślony przez przyjaciela dzieci prof. Edwarda Madeyskiego, Lwów 1893, s. 13; Żeby nie chorować. Poradnik dla tych, którzy chca żyć dtugo a zdrowo, Warszawa 1893, s. 185; Ks. S. Kneipp, Dziecko zdrowe i chore. Poradnik dla matek i ojców troskliwych, Warszawa 1895, s. 35-36; Praktyczny przewodnik wychowania przez Henryka Wernica, Warszawa 1891, s. 11-12; O wychowaniu macierzyńskim, przez Zofia Kowerską, Warszawa 1894, s. 15; Lekarz domowy. Racjonalny poradnik lekarski dla chorych i zdrowych, ułożył dr Aleksander Harasowski, Lwów 1900, s. 99; Dr L. Sonderegger, Podstawy ochrony zdrowia, w przekładzie i z przemową dr-a E. Biernackiego, Warszawa 1902, s. 14; Doc. dr O. Schaeffer, Okres macierzyństwa, przeł. dr W. Hojnacki, w: Księga zdrowia, czyli nauka pielęgnowania zdrowia, przekł. polski pod redakcją dra W. Hojnackiego, t. IV, Lwów 1907, s. 180; Doc. dr J. Trumpp, Wiek dziecięcy, przeł. dr W. Hojnacki, w: ibidem, s. 216; Dr S. Kopczyński, Szkice higieniczno-wychowawcze. Z dziedziny higieny domowej i szkolnej, Warszawa 1900, s. 219; Jak pielegnować dzieci zdrowe i jak leczyć chore, podług Ks. S. Kneippa streścił Przyjaciel zdrowia, Warszawa 1914, s. 10; Rady i wskazówki jak ustrzec się chorób płucnych. Szkic popularny, napisał dr Antoni Gros, Warszawa 1903, s. 80; Dr Z. Taussig, Dziecko do lat dwóch. Rady i wskazówki dla matek przy odżywianiu i pielęgnowaniu dzieci, tudzież zapobieganie ich chorobom, przekł. dra J. L., Warszawa 1901, s. 8; M. Biehler, Higiena dziecka, Warszawa 1905, s. 119-120; Upominek dla matek, s. 8; O budowie i pielegnowaniu ciała ludzkiego podczas zdrowia i choroby, napisał i 60-ma rycinami objaśnił dr Henryk Kowalki, Lwów 1902, s. 214; Matka i dziecko. Wychowanie fizyczne i moralne dzieci do lat 7-miu (w okresie przedszkolnym) z J. v. Wedella, przeł. St. S., Warszawa 1902, s. 44; Rady dla młodych mężatek, napisał dr J. Stella-Sawicki, Warszawa 1903, s. 53; Prof. dr M. Rubner, Odżywianie i nasze środki spożywcze, Lwów 1907, s. 46; Dr A. Fischer-Dueckelmann, s. 365; F. E. Bilz, Nowe lecznictwo przyrodne, Lipsk 1903, s. 378; Pielęgnowanie chorych, oprac. dr J. Starzewski, Lwów 1912, s. 242; H. Lotzky, Poznaj dusze dziecka twego, thum. P. FR, Warszawa 1914, s. 16; Dr med. S. Breyer, Lekarz domowy, Kraków 1911, s. 31; Dr W. Hojnacki, Higiena kobiety, Lwów 1910, s. 366; Domowa pomoc. Książka dla dobra chorej ludzkości, Hanower 1910, s. 92; Nasz dom. Poradnik praktyczny, gospodarczo-spoleczny dla kobiety polskiej, pod red. Lucyny Kotarbińskiej, Warszawa 1914, s. 292; Dr med. M. Biehler, Podręcznik higieny, Warszawa - Kraków 1916, s. 151, 450; Nauka położnictwa dla położnych w krótkim zarysie napisana przez prof. dra Adama Sołowieja, Lwów 1911, s. 31; C. Plater-Zyberkówna, Na progu małżéstwa, Warszawa 1918, s. 342; J. Payot, op. cit., s. 45.

13 Na czem opiera się wychowanie, s. 11. 
wcale nie karmi ${ }^{14}$, macica obkurcza się szybciej, rzadziej przychodzi tzw. gorączka mleczna, nie pojawia się regularność (miesiączka). Jednocześnie przestrzegano, iż rezygnacja z karmienia powodować mogła choroby macicy (obrzęki, katary i skrzywienia), raka piersi, a wstrzymywanie pokarmu, obok bólu, zapaleń i ropienia gruczołów piersiowych, mogło prowadzić do obłędu, chorób nerwowych, a w skrajnych przypadkach, jak podawano, nawet do bezdzietności ${ }^{15}$. Również podawanie dziecku niewłaściwego pokarmu, innego niż mleko matki, powodować miało u niego zaflegmienie, zapalenie i zmięknienie kiszek, dalej niestrawność, skłonność do robactwa, brak wyżyienia, powstrzymanie naturalnego rozwoju tak ciała jak i ducha, wyrzuty skórne, choroby kości, kurcze, wychudnięcie $i$ śmierć sama ${ }^{16}$. Konieczność karmienia piersią przez rodzone matki uzasadniano także wyjątkową więzią emocjonalną pomiędzy matką a dzieckiem, która rodziła się podczas tej czynności. Powierzenie dziecka pod opiekę mamki nie tylko nie sprzyjało powstawaniu tej więzi, ale i pozbawiało matkę uroków macierzyństwa - pierwszego uśmiechu malucha, pierwszego słowa, kroku, wszystkich tych momentów w rozwoju dziecka, które są niepowtarzalne i wyjątkowe, a których można doświadczyć tylko wtedy, jeśli się jest z dzieckiem na co dzieńn ${ }^{17}$.

Argumentem często wykorzystywanym przez zwolenników naturalnego karmienia piersią przez matki był odsetek śmiertelności niemowląt. W połowie XIX w. powoływano się na statystyki podające, że w pierwszym roku życia umierało z czworga, pięciorga narodzonych dzieci jedno, zaś w całym wieku dziecinnym (od narodzin do 7 roku życia) umierała niemal połowa z dzieci. Pół wieku później (1902 r.) podawano np., że ze stu żywo narodzonych dzieci dwadzieścioro pięcioro nie dożywało roku. Co szczególnie istotne, znaczny odsetek wśród nich stanowiły maluchy karmione i pielęgnowane przez mamki. Statystyki takie przywoływano przez cały analizowany okres w wielu poradnikach, wyraźnie podkreślając, iż wśród zmarłych dzieci najmniejszą liczbę stanowiły zawsze te, które karmione były piersią matki ${ }^{18}$. Znacznie mniejsza śmiertelność wśród dzie-

${ }^{14}$ Poradnik dla mlodych matek, s. 20; Dr E. Brucke, op. cit., s. 3; F. E. Bilz, op. cit., s. 378; Dr Z. Taussig, op. cit., s. 9; Doc. Dr O. Schaeffer, op. cit., s. 183; Doc. dr J. Trumpp, op. cit., s. 217; Pielegnowanie chorych, s. 242.

15 Poradnik dla młodych matek, s. 21, 104; Dr W. Hojnacki, op. cit., s. 366-267; Dr med. S. Breyer, op. cit., s. 31; F. E. Bilz, op. cit., s. 378-379; Dr Z. Taussig, op. cit., s. 9; Dyjetetyka dzieci, s. 17; Doc. dr O. Schaeffer, op. cit., s. 183; Doc. dr J. Trumpp, op. cit., s. 217-218; Medycyna ludowa, s. 85; Rady dla mtodych mężatek, s. 57-58, 62-63.

${ }^{16}$ Poradnik dla mlodych matek, s.104; Chowanna, czyli system pedagogiki narodowej, s. 369.

17 Wychowanie dziecka wedtug B.H. Gausserona, s. 19; Poradnik dla młodych matek, s. 102; Jak zachować dziecko zdrowem?, s. 25; C. Plater-Zyberkówna, op. cit., s. 343-344; Dr L. Sonderegger, op. cit., s. 116; Praktyczny przewodnik wychowania, s. 13.

${ }_{18}$ Karmienie piersią matczyna podwyższa prawdopodobieństwo utrzymania dziecka przy życiu o 200\%, w: Dr med. L. Natanson, op. cit., s. 139; Nawet przy żywieniu dziecka przez mamke, śmiertelność jest większa, aniżeli gdy matka sama karmi swe dziecko, bo mleko obcej kobiety, różniacej się organizacją nerwowa i całym ustrojem od matki dziecka, stanowi częstokroć pokarm niezdrowy dla tego ostatniego, w: Rady dla mtodych mężatek, s. 56; Dokładne statystyki śmiertelności niemowląt patrz: Poradnik dla młodych matek, s. 59-60; Jak zachować dziecko zdrowem?, s. 46; Higiena zastosowana do potrzeb życia osobniczego i społecznego oraz do rzeczy krajowych, napisał Bolesław Lutostański. Higiena ogólna, Lwów 1873, s. 54, 73-74; Dr med. M. Biehler, Podręcznik higieny, s. 150-15; Zasady higieny. Wskazówki popularne pielęgnowania zdrowia, wolny prze- 
ci karmionych piersia własnej matki znajduje wyttumaczenie nie tylko $w$ chemicznych własnościach mleka kobiecego, ale także w jego wartości biologicznej, oraz w okolicznościach towarzyszacych karmieniu przez matkę, w bliższym kontakcie matki z dziecięciem, $w$ troskliwszej opiece, $w$ większej odporności dziecka na choroby [...] Powyższe uwagi powinny przekonać kobiete, że dla błahej przyczyny nie można usuwać się od karmienia, nie można zwalać własnych obowiązków na mamkę, na istotę najczęściej brudna $i$ złą, obca dla dziecięcia, częstokroć chora, a w każdym razie zaniedbująca $w$ ten sposób swoje własne dzieci ${ }^{19}$ - pisał w początku wieku XX dr Władysław Hojnacki.

W środowiskach lekarskich i higienicznych krytykowano praktykę zatrudniania mamek, powszechnie panującą wśród kobiet z możnych warstw społecznych. Zatrudnianie mamek wśród zamożnych warstw polskiego społeczeństwa nazywano swoistą modą, zwyczajem, który stał się powszechnym i praktykowanym przez większość pań z rodzin arystokratycznych, szlachecko-ziemiańskich czy bogatych rodzin mieszczańskich ${ }^{20}$. Powodem, dla którego zwyczaj ten był praktykowany w większości zamożnych rodzin była wygoda kobiet, niechęć rezygnacji z tzw. światowego życia - karmienie wymagało bowiem stałego pobytu matki w domu i wielu wyrzeczeń, wyłączając ją z życia towarzyskiego, utrudniając noszenie modnych strojów, opieka nad dzieckiem ograniczała możliwość przyjmowania gości, spożywania dowolnych potraw i napojów. Nie można karmiac za granice wyjechać, ani do wód, ani nawet do miasta odleglejszego, jeśli się na wsi mieszka. Nie można bywać na wieczorkach, balach, redutach, koncertach i itp. zabawach, lecz trzeba siedzieć przy kołysce jak niewolnica ${ }^{21}$ - pisał autor poradnika pedagogicznego z lat 80. XIX w., Ksawery Pałuczanin. Dlatego matki, usprawiedliwiając zatrudnianie mamek, wskazywały na brak czasu, liczne obowiązki domowe i towarzyskie, które uniemożliwiały regularne karmienie. Powszechnie panowało także przekonanie o zbyt delikatnym i słabym organizmie młodej matki, której mleko rzekomo nie miało odpowiedniej ilości składników odżywczych niezbędnych dla dziecka (ta sama kobieta miała natomiast dość sił, by aktywnie brać udział w barwnym i wystawnym, często nocnym życiu towarzyskim). Wiele kobiet sądziło, że karmienie dziecka oddziaływa niekorzystnie na pięknośćc ${ }^{2}$ - karmiąc, kobieta rzekomo miała tracić świeżość, urodę i zdro-

kład dra I. Świętochowskiego, Warszawa 1902, s. 150; Dr W. Hojnacki, op. cit., s. 366-368; Prof. dr J. Orth, Cel i zadanie pielęgnowania zdrowia, przeł. prof. W. Schreiber, Lwów 1907, s. 43-44; Dr A. Fischer-Dueckelmann, op. cit., s. 734; dr M. Biehler, Higiena dziecka, s. 148-149; Ks. S. Kneipp, Dziecko zdrowe i chore, s. 39-42; Lekarz domowy, s. 100; Dr L. Sonderegger, op. cit., s. 124-125; Rady dla młodych mężatek, s. 56; Praktyczny przewodnik wychowania, s. 12.

19 Dr W. Hojnacki, op. cit., s. 368-369.

${ }^{20}$ „W wyższych klasach społeczeństwa panuje zwyczaj, że matki niemowląt swych nie karmią same, lecz trzymają do tego najemne żywicielki. Jeżeli zaś która z pań sama dziecię swe karmi, to wypadek ten przechodzi zaraz do wiadomości publicznej jako rzecz dla jednych nadzwyczajna, dla drugich dziwaczna", w: Szkice pedagogiczne, s. 71 .

${ }^{21}$ Ibidem, s. 72.

${ }^{22}$ Jak zachować dziecko zdrowem?, s. 37; Higiena polska, t. 1, s. 107; Zasady higieny, s. 150; C. PlaterZyberkówna, op. cit., s. 344; Dr A. Fischer-Dueckelmann, op. cit., s. 738; Bilz, op. cit., s. 381; Dr Z. Taussig, op. cit., s. 8; Lekarz domowy, s. 99; Doc. dr J. Trumpp, op. cit., s. 218-219; Rady dla młodych mężatek, s. 56; Dr S. Kopczyński, op. cit., s. 220. 
wie. Wreszcie, jak czytamy w poradniku higienicznym z połowy XIX w., przyczyną niechęci do karmienia piersią był snobizm i moda na cudzoziemszczyznę: $U$ nas matki wyższej sfery nie karmia dzieci swoich dlatego, że to nie jest moda we Francji; u nas matki średniej sfery nie karmia dzieci swoich dlatego, że chciałaby uchodzić za kobiety z wyższej sfery, zwłaszcza, gdy sa piękne i gdy im przychodzi z łatwościa żyć z osobami wyższego urodzenia ${ }^{23}$. Panie, które pochodziły z wyższych warstw społecznych zakładały, że karmienie dziecka jest czynnością niegodną ich stanu, zrównującą je w porządku społecznym w wieśniaczkami czy innymi ubogimi matkami ${ }^{24}$. W początku wieku XX można było spotkać także powód rezygnacji z karmienia, jakim była praca zawodowa kobiety poza domem, np. w biurze, handlu, rzemiośle, przemyśle ${ }^{25}$. Dodatkowo wskazywano na winowajcę zatrudniania mamek, jakim bywał często ojciec dziecka. To on nakłaniać miał żonę do rezygnacji z karmienia i do zatrudnienia płatnej karmicielki. Tłumaczono obawy mężczyzn ograniczaniem przez dziecko i jego karmienie normalnego funkcjonowania kobiety karmiącej, powodującym trudności we właściwym prowadzeniu domu, niemożność wychodzenia z karmiącą żoną na spotkania towarzyskie, na bale, do teatrów, na koncerty, a przede wszystkim obawę przed nieprzespanymi nocami - Pan lubi spać spokojnie, a noce w pobliżu matki karmiacej swe dziecko nie należa do najspokojniejszych. Dzieciak placze, matka się budzi - pan obliczywszy to wszystko, woli zabronić matce karmienia, przyjąć mamkę i ulokować ja w wraz z dzieckiem w osobnym poko$j u^{26}$. Domyślać się należy, że powodem niechęci mężów do karmienia piersią było utrudnione spełnianie obowiązków małżeńskich przez żonę ${ }^{27}$.

Istniały jednak sytuacje, w których matka nie mogła samodzielnie karmić noworodka i niemowlęcia. Wskazywano na kilka powodów, zwalniających matkę z tego naturalnego obowiązku. Należały do nich choroby kobiety - wyliczano tu obłąkanie, choroby nerwowe, anemię, suchoty, choroby serca, kołtun, szkorbut, epilepsję, skrofuły, raka, choroby nerek, puchlinę wodną, wyrzuty skórne (wrzody, liszaje), choroby weneryczne, owrzodzenia czy narośle na piersiach, a także ospę, szkarlatynę, tyfus, błonicę i ciężką gorączkę połogową (w niektórych jednak wskazanych przypadkach, np. chorobach serca, kiedy choroba nie miała ciężkiego przebiegu i nie było zagrożenia zarażenia się przez dziecko, matka - za zgodą lekarza - mogła karmić sama). Niemożliwym było naturalne karmienie także wtedy, kiedy kobieta miała niewłaściwie zbudowane brodawki, uniemożliwiające ssanie, kiedy z różnych przyczyn nie miała pokarmu, a także, kiedy wkroczyła w piąty dziesiątek życia. Należało zrezygnować z karmienia również wówczas, kiedy stosunki rodzinne i otoczenie karmiącej powodowało u niej przeciągły stan zdenerwowania, fru-

${ }^{23}$ Higiena polska, t. 1, s. 107.

${ }^{24}$ „Dama czy pani ma sobie za niehonor czynić to, co czyni każda zwyczajna kobieta, to jest karmić piersiami własne dziecko. Następnie pozycja, majątek nie pozwalają osobie dystyngowanej zajmować się tak niskimi rzeczami. Zresztą stać na to damę, czemuż więc nie ma trzymać sobie karmicielki?”, w: Szkice pedagogiczne, s. 71; Por. E. Badinter, Historia miłości macierzyńskiej, przeł. K. Choiński, Warszawa 1998, s. 67-71.

25 Doc. dr O. Schaeffer, op. cit., s. 184-185. 115.

${ }^{26}$ Wychowanie dziecka wedtug B. H. Gausserona, s. 17-18; Zob. też: Poradnik dla młodych matek, s. 108,

27 E. Badinter, op. cit., s. 69-70. 
stracji, zmartwień i niepokoju, który wraz z mlekiem mógł przechodzić na dziecko i szkodzić jego rozwojowi. Wreszcie nie powinna karmić kobieta, którą cechowała wrodzona złośliwość, a także ta, która spodziewała się kolejnego dziecka ${ }^{28}$. Lekarze i higieniści, doszukując się tak częstej niemożności karmienia piersią przez zamożne kobiety stwierdzali, że powodem było ściskanie piesi i gruczołów mlecznych gorsetami i stanikami już od 7-8 roku życia, powodując niewłaściwe ich rozwinięcie (np. wklęsłość brodawek, uniemożliwiającą dziecku ssanie $)^{29}$. Na początku XX w. dr Matylda Biehler podawała, że jak wykazały badania, na 100 kobiet zaledwie $2 \%$ nie mogło samodzielnie karmić swoich dzieci i przyczyną tego nie był brak pokarmu, lecz choroba, bądź wadliwa budowa piersi ${ }^{30}$.

W każdym przypadku zaniechania karmienia naturalnego piersią matki należało poradzić się lekarza i dopiero po jego diagnozie - zarówno stanu zdrowia matki, jak i dziecka można było zdecydować się na rozwiązanie zastępcze - zatrudnienie mamki lub karmienie sztuczne ${ }^{31}$. Wśród autorów poradników nie było jednomyślności, które z rozwiązań miało być lepszym i zdrowszym dla niemowlęcia. Jednak większość z nich, mając na uwadze głównie troskę o zdrowie dziecka, stawiała na pokarm zastępczy naturalny mleko innej kobiety nad pokarm sztuczny. Obawiano się szumnie (szczególnie na przełomie XIX i XX i na początku XX w.) reklamowanych surogatów mleka kobiecego kaszek, mączek, proszków słodowych, skondensowanych ekstraktów czy konserw mlecznych. Podawano w wątpliwość nawet tradycyjne karmienie mlekiem zwierząt, najczęściej krowim, które w mieście nie zawsze było dobrej jakości (często bowiem pisano o fałszowaniu mleka, rozcieńczaniu go) i mogło stać się przyczyną poważnych chorób, a nawet śmierci niemowląt. Podobne konsekwencje mogło mieć niewłaściwe sterylizowanie butelek do pokarmu sztucznego czy mleka zwierzęcego ${ }^{32}$. Mimo tych niebezpieczeństw

${ }_{28}$ Ibidem, s. 110-111; Chowanna, czyli system pedagogiki narodowej, s. 369; Rady dla matek, s. 521-522; Jak pielęgnować dzieci zdrowe, s. 10; Rady i wskazówki, s. 81; Higiena polska, t. 1, s. 111-112; Dr E. Brucke, op. cit., s. 1-2; Dr W. Hojnacki, op. cit., s. 369; Dr med. S. Breyer, op. cit., s. 35; Dr A. Fischer-Dueckelmann, op. cit., s. 738; M. Biehler, Higiena dziecka, s. 121; Dr Z. Taussig, op. cit., s. 9; Lekarz domowy, s. 99; Doc. Dr O. Schaeffer, op. cit., s. 187-189; Doc. dr J. Trumpp, op. cit., s. 219; Dr med. L. Natanson, op. cit., s. 149; Praktyczny przewodnik wychowania, s. 14.

${ }^{29}$ Choroby kobiece, s. 15, 21, 52-54; F. E. Bilz, op. cit., s. 376; Dyjetetyka dzieci, op. cit., s. 14; Żeby nie chorować, s. 189; Lekarz domowy, s. 99; Doc. dr J. Trumpp, op. cit., s. 220-221; Dr L. Sonderegger, op. cit., s. 116; Rady dla młodych mężatek, s. 63-69; Dr S. Kopczyński, op. cit., s. 219.

${ }^{30}$ Dr med. M. Biehler, Podręcznik higieny, s. 151.

31 Wychowanie dziecka wedlug B. H. Gausserona, s. 14; Chowanna, czyli system pedagogiki narodowej, s. 370; Higiena polska, t. 1, s. 33; Zasady higieny, s. 150-151; Dr med. S. Breyer, op. cit., s. 35; Domowy poradnik lekarski, napisała dr Jan Stella-Sawicki, Lwów 1888, s. 19; Podręcznik do leczenia chorób środkami homeopatycznymi dla użytku świattej publiczności i lekarzy, ułożony przez dra H. Cyrklera, Warszawa 1903, s. 483; Doc. dr O. Schaeffer, op. cit., s. 181; Dr L. Sonderegger, op. cit., s. 117; Pielegnowanie chorych, s. 248 .

32 Wychowanie dziecka wedtug B. H. Gausserona, s. 14- 15; Poradnik dla młodych matek, s. 173-178; Chowanna, czyli system pedagogiki narodowej, s. 370-371; Jak zachować dziecko zdrowem?, s. 37-38, 46; Kaszel $i$ choroby piersiowe. Ich przyczyny, leczenie $i$ zapobieganie. Poradnik dla wszystkich opracował dr P. Niemeyer z 6 rysunkami. Tłumaczył z trzeciego wydania dr J. St, Warszawa 1887, s. 5; Skrofuty (zolzy), s. 44; Jak pielęgnować dzieci zdrowe, s. 11-12; Rady i wskazówki, s. 77; Higiena polska, t. 1, s. 34, t. 2, 
jednak cześć autorów utrzymywała, że wszelkie względy, moralne i społeczne oddaja pierwszeństwo sztucznemu karmieniu nad mamka ${ }^{33}$.

W wielu poradnikach krytykujących zatrudnianie mamek znajdujemy argumenty przywołujące niedolę dzieci opuszczanych przez mamki. By bowiem mamka mogła nająć się do karmienia cudzego dziecka, najpierw musiała urodzić własne, które najczęściej pozostawiała pod opieką bliskich czy innej kobiety, oczywiście za odpowiednim wynagrodzeniem. Bywało też, że oddawała je do przytułku ${ }^{34}$. Sztuczne karmienie niemowląt ma liczne ujemne strony, pod względem moralnym i społecznym stoi o wiele wyżej od nagannego, a wielce rozpowszechnionego zwyczaju, najmowania obcych kobiet, które skazuja na ciężka niedolę, na śmierć niechybna, a często okrutna własne dzieciny, by za kęs chleba wyręczyć bogatsze, w lepszych warunkach żyjace matki. Wiele, bardzo wiele powiedzieć by można na ten temat, nich jednak każda matka sama pomyśli o tej ranie społecznej, niech wniknie $w$ dole tych setek tysięcy niewinnych niemowląt, z pewnościa, jeśli iskra w niej nie zamarła, samolubnie i lekkomyślnie nie zrzuci ciężaru na obce bar$k i^{35}$. Uświadamiano kobietom rezygnującym z karmienia i zatrudniającym mamki, że one także pośrednio biorą udział w uśmiercaniu niemowląt tych matek, które zabierając mleko swoim dzieciom, karmią ich pociechy. Lekarze opisywali sytuacje, kiedy to dzieci oddane na wychowanie innym kobietom (tzw. fabrykantkom aniołków - z powodu wysokiej śmiertelności powierzanych im niemowląt), często chorowały z powodu niewłaściwej pielęgnacji, zaniedbania, brudu i niedożywienia, a niejednokrotnie w konsekwencji umierały. Dla matki, która ,poszła w mamki”, była to, jak często podawano, najlepsza sytuacja, bo zwalniała ją z comiesięcznych kosztów utrzymania swojego dziecka (a bywało, że mamka rodziła kolejno kilkoro dzieci i płaciła za utrzymanie kilkorga). Kiedy już, jak pisano, nielicznym dzieciom mamek udawało się przeżyć, wyrastały zwykle na dzieci słabe, wątłe, często mające krzywicę, a dorastanie w niekorzystnych warunkach wychowawczych powodować miało, że stawały się ,zakałami społeczeństwa"36. By zapobiegać śmiertelności, chorowitości i demoralizacji dzieci pozostawianych przez matki „,idące na mamki” postulowano, by możne panie, kierując się dobrem dzieci własnych i mamek, starały się za wszelką cenę karmić piersią. Zwolnić je od tego obowiązku mogły jedynie choroby, zaś o rezygnacji z karmienia powinien decydować jedynie lekarz (a najlepiej dwóch). Mamką mogła zostać każda kobieta, której dziecko zmarło (oczywiście o ile była zdrową), lub taka, która mogła karmić jednocześnie dwoje dzieci - swoje i państwa. Zatrudniać należało jedynie takie kobiety, które potrafiły udowodnić, że opuściły swe dziecko dla zarobku, ale zostawiały je pod dobrą opieką i że krewna lub zna-

s. 230-231; Matka i dziecko, s. 47; Dr med. M. Biehler, Podręcznik higieny, s. 153, 176-181; Prof. dr M. Rubner, op. cit., s. 47-48; Dr med. S. Breyer, op. cit., s. 35, 40; Dr Z. Taussig, op. cit., s. 41-68.

${ }^{33}$ Matka i dziecko, s. 47.

34 Tragizm wczesnego dzieciństwa takich niemowląt, oddanych do przytułków przez matki trudniące się maczarstwem opisuje Antoszka - zob.: Przy kądzieli, s. 72-78.

${ }^{35}$ Na czem opiera się wychowanie, s. 11-12; zob. też: Poradnik dla młodych matek, s. 103; Doc. dr J. Trumpp, op. cit., s. 230.

${ }^{36}$ Poradnik dla młodych matek, s. 107; Higiena polska, t. 1, s. 108-109; Dr W. Hojnacki, op. cit., s. 369; Dr A. Fischer-Dueckelmann, op. cit., s. 738. 
joma kobieta karmić je będzie przynajmniej cztery miesiące piersią. Jeśli w przyszłości lekarze, rozsądni mężowie $i$ krewni młodych, chwiejnych i błądzacych kobiet z energia popierać będa nasza pierwsza zasadę - każda matka powinna sama karmić - znikna ze świata mamki i niejednemu dzieciatku zachowa się życie $e^{37}$. Niestety, podkreślana w poradnikach popularność zatrudniania mamek w zamożnych rodzinach pozwala stwierdzić, że większość z tych zaleceń pozostawała jedynie w formie postulatów, praktyka zaś pozostawiała wiele do życzenia.

Kiedy rodzice decydowali się na zatrudnienie najemnej karmicielki, na stronach poradników podpowiadano, jak znaleźć kobietę właściwą, której pokarm będzie najbardziej odpowiedni dla dziecka. Zdając sobie sprawę z wagi problemu, w niektórych z poradników autorzy poświęcali temu zagadnieniu osobne, mniej lub bardziej obszerne rozdziały czy fragmenty.

Kto zwykle zostawał mamką? Najczęściej mamki rekrutowały się spośród kobiet wiejskich lub z ubogiego mieszczaństwa. Nie były to zwykle mężatki (choć i takie się zdarzały), lecz panny z dziećmi, które raz zatrudniwszy się na stanowisku mamki, zakosztowawszy w dobrobycie i wygodach, rodziły kolejne dzieci, które oddawały na wykarmienie i wychowanie innym, by nadal utrzymać swoje stanowisko pracy ${ }^{38}$.

Gdzie należało szukać mamki? W poradnikach zalecano, by szukając karmicielki, udać się do znajomej akuszerki, okolicznego zakładu położniczego, sugerowano także poszukiwanie przez ogłoszenia prasowe. Najbezpieczniejsze było zatrudnienie mamki poleconej przez akuszerkę, która znała stan zdrowia położnicy, jej dziecka, potrafiła poświadczyć o jakości jej mleka. Ten sposób był oczywiście możliwy do realizacji dla rodzin mieszkających w miastach lub w niewielkim od nich oddaleniu. Rodziny ziemiańskie czy arystokratyczne, mieszkające w wiejskich dworach czy pałacach oddalonych od większych miejscowości, zwykle poszukiwały mamki w okolicznych wioskach. Innym sposobem poszukiwana karmicielek były kantory stręczeń, znajdujące się przeważnie w miastach i miasteczkach. Chcąc zatrudnić mamkę w taki sposób, należało wymagać od niej świadectwa lekarskiego o stanie zdrowia i rękojmię moralności ${ }^{39}$, choć jak ostrzegał Ksawery Pałuczanin, ja w uczciwość mamek, których dostarczaja po miastach osobne biura informacyjne zupetnie nie wierze $e^{40}$.

Mamka tak wielki na przyszłość niemowlęcia wpływ wywiera, że jej wyborowi więcej wartałoby poświęcić troskliwości jak się zwykle dzieje, albowiem mało u nas bacza na przymioty, więcej waża polecenie baby albo jakiejś znajomej. Wszakże pamiętać należy, że nierzadko, spotem z mlekiem mamki odziedzicza niemowle życie lub śmierć, zdrowie lub chorobę [...]. W wyborze mamki baczyć należy na jej przymioty fizyczne, własności

\footnotetext{
${ }^{37}$ Ibidem, s. 738-739

38 „Mamki u nas najczęściej wynikają z zbliżeń przypadkowych, prawem nieuświęconych, nieczystych”, w: Higiena polska, t. 1, s. 33, 108; Zob. też: C. Plater-Zyberkówna, op. cit., s. 343.

${ }^{39}$ Matka i dziecko, s. 78; Dr med. Th G. Koring, Higiena skromności, podług drugiego wydania niemieckiego opracował dr A. Fabian, Warszawa 1894, s. 33; Szkice pedagogiczne, s. 76; Rady dla młodych mężatek, s. 99.

${ }^{40}$ Szkice pedagogiczne, s. 76; Dr S. Kopczyński, op. cit., s. 222.
} 
mleka i przymioty moralne ${ }^{41}$ - radził doktor Hipolit Terlecki w poradniku dla matek już w 1835 r. Zalecenie to aktualne pozostało do początku wieku XX. Zarzucano najemcom, że przy wyborze karmicielki kierowali się jedynie faktem, by dziecko jej było wiekiem zbliżone do dziecka, które miała karmić. Poszukiwania odpowiedniej kandydatki radzono prowadzić już podczas ciąży ${ }^{42}$. Najlepiej, by była ona wiekiem zbliżona do wieku matki lub znajdowała się pomiędzy 20 a 32-34 rokiem życia (młodsze niż 20 lat miały być lekkomyślne, a po 34 rzadko kiedy miewać miały dobre mleko; we wskazanym okresie wydzielanie mleka u kobiet trwało najdłużej). Wybierając mamkę, należało szukać mężatki, co miało dawać gwarancję jej moralnego prowadzenia się (choć większość mamek było pannami niezamężnymi ${ }^{43}$ ), taką, która rodziła i karmiła już drugie lub kolejne dziecko (miała już bowiem doświadczenie w opiece nad noworodkiem i niemowlęciem, zaś zdrowie wykarmionego przez nią pierwszego dziecka było doskonałą rękojmią) i pochodzącą ze wsi (miała być zdrowszą niż mieszczanki) ${ }^{44}$. Najlepiej, by od czasu porodu mamki minęło przynajmniej 6 tygodni, tak, by zdążyła ona wydobrzeć i nabrać sił, a najlepiej było odczekać trzy miesiące od porodu, co miało służyć odkarmieniu i zmniejszyć ryzyko śmierci jej własnego dziecka. Nie powinno się jednak zatrudniać mamki będącej dłużej niż 6 miesięcy po porodzie, gdyż skład pokarmu wtedy ulegać miał zmianie i nie nadawał się do karmienia dziecka nowo narodzonego. Najlepiej oczywiście, by mamka w tym samym czasie rodziła dziecko co pracodawczyni, gdyż wtedy skład mleka był odpowiedni do potrzeb oseska w określonym okresie życia ${ }^{45}$. Powszechnie panujące przekonanie, że jakość pokarmu zależy od powierzchowności - wyglądu czy postury karmicielki, obfitości kształtów (im kobieta bardziej tłusta, tym bardziej pożywny będzie jej pokarm), wielkości piersi czy koloru włosów (ciemnowłose stawiano przed czarnowłosymi i blondynkami, rude miały być zbyt namiętne i gwałtowne) już w połowie XIX w. w środowisku lekarskim uznano za niesłuszne i uświadamiano o tym fakcie czy-

${ }^{41}$ Rady zachowania się niewiast czasu brzemienności, porodu, połogu, tudzież o pielęgnowaniu niemowląt $i$ wyborze mamki, napisał Hipolit Terlecki, medycyny doktor, Kraków 1835, s. 232.

42 Jeżeli zaś która z matek znajduje się $w$ tym położeniu, że nie może sama podjąć się karmienia owocu miłości $i$ żywota swego, do czego przede wszystkim własna wola, a nie namowa lub same życzenia męża sa konieczne [...] matka ta, mówię, winna już wśród ciąży starać się o stosowna mamkę, aby zaraz od pierwszej chwili podjęta troske o powierzony jej skarb familii, w: Poradnik dla młodych matek, s. 115.

${ }^{43}$ W rzadkich tylko wypadkach udaje się znaleźć kobietę zamężna, zazwyczaj przychodzi przyjąć niezamężna, a takie po największej części nie odznaczają się uczciwościa i innymi przymiotami, w: Jak zachować dziecko zdrowem?, s. 38 .

${ }^{44}$ Poradnik dla młodych matek, s. 117-118; Jak zachować dziecko zdrowem?, s. 38; Jak pielęgnować dzieci zdrowe, s. 1; Higiena polska, t. 1, s. 113; Matka i dziecko, s. 79; Dr E. Brucke, op. cit., s. 31-32; Prof. dr M. Rubner, op. cit., s. 46; Dr A. Fischer-Dueckelmann, op. cit., s. 739; Rady zachowania się niewiast czasu brzemienności, s. 233; Dr Z. Taussig, op. cit., s. 31; Dyjetetyka dzieci, s. 14, 18; Medycyna ludowa, s. 85; Dr med. L. Natanson, op. cit., s. 151; Rady dla młodych mężatek, s. 96-97; Domowa pomoc, s. 92.

${ }^{45}$ Poradnik dla młodych matek, s. 117-118; Jak zachować dziecko zdrowem?, s. 38; Jak pielęgnować dzieci zdrowe, s. 1; Higiena polska, t. 1, s. 113; Matka i dziecko, s. 79; Dr E. Brucke, op. cit., s. 31-32; Prof. dr M. Rubner, op. cit., s. 46; Dr A. Fischer-Dueckelmann, op. cit., s. 739; Rady zachowania się niewiast czasu brzemienności, s. 233; Podręcznik do leczenia chorób, s. 489; Dr med. L. Natanson, op. cit., s. 153. 
telników literatury poradnikowej ${ }^{46}$. Jedynie, kiedy do wyboru były dwie mamki, które wydawały się równo zdrowe i których dzieci również dobrze rosły, radzono wybrać tęższą, gdyż u tej było mniejsze prawdopodobieństwo gruźlicy ${ }^{47}$.

Najbardziej wiarygodnym i pewnym sposobem znalezienia ,,pewnej” mamki była diagnoza lekarska, dlatego sugerowano, by kandydatkę na karmicielkę dokładnie przebadał zaufany lekarz. Miało to zapobiegać przenoszeniu ewentualnych chorób z mamki na dziecko (wśród najczęściej występujących i niebezpiecznych chorób podawano np. choroby weneryczne, suchoty, wyrzuty skórne, skrofuły, choroba angielska, szkorbut i in$\left.\mathrm{ne}^{48}\right)$. Badanie polegać miało na gruntownym obejrzeniu stanu ciała kandydatki na mamkę, począwszy od czystości głowy, włosów (kołtun, wszy) stanu cery, paznokci i skóry ('świerzb, wypryski, liszaje, wrzody), stanu jamy ustnej, dziąseł, języka (świeży oddech, zdrowe zęby i dziąsła), diagnozy czy nie ma powiększonych gruczołów pod szyją, pod pachami, po dokładne oględziny piersi (blizny, stan brodawek, jędrność, kolor skóry) i części rodnych (blizny, narośle, upławy). Należało przeprowadzić dokładny wywiad o liczbie porodów, przebytych chorobach i stanie zdrowia dzieci własnych i wcześniej karmionych - o ile dzieci mamki przychodziły na świat nieżywe lub umierały w wieku noworodkowym czy niemowlęcym, nie należało takiej kobiety zatrudniać. Musimy wspomnieć o tym, że dosyć często wydarza się przeniesienie chorób zakaźnych, niszczacych organizm w wysokim stopniu, ze stug, a zwłaszcza z mamek, karmiacych dzieci [...] Szkoda wielka, że dotąd nie zastrzė̇ono prawem, aby wszystkie kobiety, pragnace stużyć $w$ charakterze mamek podlegały oględzinom lekarskim ${ }^{49}$ - ubolewano w jednym z poradników. Przestrzegano rodziców, że mamki, chcąc nająć się na intratną posadę w bogatym domu często najróżniejszymi sposobami zatajały przebyte choroby, narażając tym samym dziecko na zarażanie się nimi i dodatkowo, szczególnie dziewczęta miejskie, prze-

${ }^{46}$ Mimo to w niektórych poradnikach, nawet pisanych przez lekarzy znaleźć można było tego typu porady: Mamki blondynki sa lagodniejszego usposobienia, cierpliwsze, ale leniwe i senne, brunetki maja pokarm żyźniejszy, ale bywaja porywcze, namiętne. Jeżeli matka dziecka jest mocna brunetka, lepiej wziąć mamkę blondynke i odwrotnie. Wptywa to na umiarkowanie ciałoskładu dziecięcia, w: Dr med. L. Natanson, s. 152; Zob. też: Medycyna ludowa, s. 86; Rady dla młodych mężatek, s. 97.

${ }^{47}$ Przymioty fizyczne [...] są zdrowy wyglą, rozwinięte piersi, pewna tęgość, przy naciśnięciu taty wytrysk mleka [...] Czasami, mimo zdrowych pozorów karmiącej, dziecko ciagle mało zyskuje na wadze, wtedy koniecznie trzeba mamkę zmienić, w: Matka i dziecko, s. 79-80; Zob. też: Poradnik dla młodych matek, s. 112; Jak zachować dziecko zdrowem?, s. 38-39; Higiena polska, t. 1, s. 113; L. Weitzenblut, op. cit., s. 126-144; Matka i dziecko, s. 79-80; Dr E. Brucke, op. cit., s. 25; Dr Z. Taussig, op. cit., s. 31; Medycyna ludowa, s. 86.

${ }^{48}$ Poradnik dla mlodych matek, s. 75, 105; Higiena polska, t. 1, s. 33; Dr E. Brucke, op. cit., s. 25-26; dr A. Puławski, Co to sa suchoty i jak się od nich uchronić?, Warszawa 1916, s. 26-27; O wychowaniu macierzyńskim, s. 64.

${ }^{49}$ Choroby kobiece, ich zapobieganie i leczenie. Poradnik dla kobiet, napisał dr J. Herm. Baas. thum. dr J. St, Warszawa 1889, s. 13; Jak pielęgnować dzieci zdrowe, s. 10; Rady i wskazówki, s. 81; Higiena polska, t. 1, s. 33-34; O budowie i pielęgnowaniu ciała ludzkiego, s. 215; Matka i dziecko, s. 78; Dr E. Brucke, op. cit., s. 25; Nauka położnictwa, s. 33; Rady zachowania się niewiast czasu brzemienności, s. 234-236; M. Biehler, Higiena dziecka, s. 121; Dr Z. Taussig, op. cit., s. 30; Dyjetetyka dzieci, s. 18-19; Podręcznik do leczenia chorób, s. 489; Lekarz domowy, s. 100; Doc. dr J. Trumpp, op. cit., s. 230; Dr med. L. Natanson, op. cit., s. 151-152; A, Józefczyk, op. cit., s. 7; Rady dla młodych mężatek, s. 95. 
bierały się w stroje włościańskie, mając świadomość o przekonaniu rodziców, że wieśniaczki są zdrowszymi, więc chętniej zatrudnianymi ${ }^{50}$.

W poradnikach można było znaleźć wskazówki, jak ocenić piersi mamki, by były właściwie zbudowane do karmienia dziecka i jak sprawdzić, czy mleko było odpowiedniej jakości. Piersi mamki powinny być umiarkowanie rozwinięte, miękkie, a brodawki miały łatwo dawać się chwytać ustami i ssać. Mleko, koloru perłowo lub srebrno białego przy uciśnięciu brodawki powinno wytryskać z łatwością z 12-15 otworków. Radzono także, by upuścić kroplę mleka na paznokieć lub szkiełko zegarka - kiedy było białe, podczas ruchu poziomego nie rozlewało się, a pionowego nie trzymało powierzchni, tylko po niej spływało, było właściwe. Gdy tak się działo, oznaczało to, że w pierwszym przypadku mleko było zbyt rzadkie i jałowe, w drugim zbyt gęste. Można było także upuścić kilka kropek do szklanki z wodą - dobry pokarm nie powinien szybko się w niej rozpływać, tworząc białe „obłoczki” (zbyt tłuste opadało na dno, rozdzielające się na nitki oznaczało „,szlamowatość”, zbyt chude barwiło wodę na jasno). Właściwie produkujące mleko piersi po ich wypróżnieniu powinny po około dwóch godzinach znów się napełniać51.

Najlepszym sposobem na potwierdzenie zdrowia i odżywczych wartości mleka mamki było jej własne zdrowe dziecko, lecz to często ukrywano, pokazując pracodawcom „pożyczone” dziecko sąsiadki czy znajomych ${ }^{52}$. Dziecko powinno być petne, pulchne, dobrze odżywione, skóra powinna być gładka, miękka, bez żadnych wyrzutów, uważać należy, by na dłoniach i piętach nie było czerwonych lub sinych plam. Jeżeli dziecko spokojnie śpi, posiada jasne, pogodne oczy, natenczas daje to rękojmię, że i jego matka jest $z$ drowa ${ }^{53}$. Doskonałą metodą sprawdzenia pożywności mleka mamki było sprowadzenie jej wraz z jej dzieckiem do domu ciężarnej jeszcze przed porodem w celu obserwacji, czy i jak dziecko przybiera od pokarmu matki. Miało to być jednocześnie okazją sprzyjającą do zapoznania się mamki z nowym otoczeniem, pracodawcami, omówienia z matką zasad i warunków opieki nad dzieckiem ${ }^{54}$.

Poszukując karmicielki, należało sprawdzić także moralność kandydatki, szczególnie, kiedy karmiła już kolejne dziecko po swoim kolejnym porodzie - mogło to sugerować, że jest osobą rozwiązłą, szukającą przygód z mężczyznami i dodatkowo obciążoną chorobami wenerycznymi. Pod żadnym pozorem nie należało zatrudniać kobiet wszetecznych, nierządnych czy nadużywających alkoholu. W miarę możliwości dobrze było

50 Poradnik dla młodych matek, s. 105, 115, 118; Jak zachować dziecko zdrowem?, s. 38-41; Rady zachowania się niewiast czasu brzemienności, s. 244-245; Rady dla młodych mężatek, s. 96.

${ }_{51}$ Poradnik dla młodych matek, s. 24, 112-113; Jak zachować dziecko zdrowem?, s. 40; Higiena polska, t. 1, s. 113; Rady zachowania się niewiast czasu brzemienności, s. 236-237; Dr Z. Taussig, op. cit., s. 30; Dyjetetyka dzieci, s.19; Dr med. L. Natanson, op. cit., s. 152; Rady dla młodych mężatek, s. 96.

52 Poradnik dla młodych matek, s. 105; Jak zachować dziecko zdrowem?, s. 39; Rady zachowania się niewiast czasu brzemienności, s. 237, 244; Dr Z. Taussig, op. cit., s. 33; Dyjetetyka dzieci, s. 19.

53 Jak zachować dziecko zdrowem?, s. 39; Higiena polska, t. 1, s. 113; Dr Z. Taussig, op. cit., s. 31; Medycyna ludowa, s. 86; Dr med. L. Natanson, op. cit., s. 152; Rady dla młodych mężatek, s. 96.

${ }^{54}$ Poradnik dla młodych matek, s. 117; Higiena polska, t. 1, s. 113. 
upewnić się o zdrowiu i moralności mamki z wywiadów, rozmów z poprzednimi pracodawcami, a także znajomymi, sąsiadami itp. ${ }^{55}$

W poradnikach czytelniczki znajdowały nawet zalecenia dotyczące urody mamki. I choć, jak już pisano, nie decydowała ona o jakości mleka, to zalecano, by mamka miała miłą i przyjemną powierzchowność, by nie budziła wstrętu w matce i domownikach, z którymi przebywała i by jej uroda była miłą dla dziecka. Nie mogła być jednak zbyt urodziwa, bo rodziło to niebezpieczeństwo uwodzenia jej ze strony mężczyzn. Również wskazywano na idealne cechy charakteru mamki, która przebywając z dzieckiem niemal bez przerwy, oddziaływała na niego swoją osobą - powinna ona mieć dobre serce, być pogodna, wesoła, gadatliwa, ale nie lekkomyślna, ponura, małomówna i posępna, bo takie cechy wpłynąc miały negatywnie na rozwój niemowlęcia. Mamka powinna być łagodna, spokojna, wytrwała, cierpliwa, wreszcie cechować ją miały zamiłowanie do porządku, skromność, obowiązkowość i pracowitość. Dyskryminować kandydatkę na mamkę miała niecierpliwość, wybuchowość, łatwe unoszenie się gniewem, lenistwo, opieszałość w wykonywaniu obowiązków, wspominania już lubieżność, rozwiązłość ${ }^{56}$.

Zatrudnienie mamki, jak się okazywało, często nie do końca było wyręką i uwolnieniem matki od obowiązków opieki nad dzieckiem. Nie myślcie zresztą, aby przybrane mamki od samych niewygód karmienia was uwalniać miały; bo niewygody, jakie z mamka się łacza, sa nieporównanie większe ${ }^{57}$ - przestrzegano matki. Kobiety, które nie z konieczności, ale ze względów towarzyskich i dla wygody swych własnych dzieci nie karmia, nie tylko biora na siebie wielka odpowiedzialność za stan zdrowia swojego dziecka, ale maja $w$ dodatku z powodu ciagłego i niezbędnego czuwania nad mamka więcej kłopotu, aniżeli gdyby same karmity ${ }^{58}$. Jak sugerowano, już sama obecność w domu nowej, obcej osoby była dla domowników dyskomfortem, a przyzwyczajenie się karmicielki do trybu życia domu trwało dość długo. Przyzwyczajenia mamki, jej obyczaje, sposób zachowania, sposób opieki i pielęgnacji nad powierzonym jej niemowlęciem nie zawsze odpowiadał pracodawcom. Kiedy więc już zatrudniono mamkę, należało zająć się kierowaniem postępowaniem karmicielki z dzieckiem i kontrolowaniem jakości powierzonych obowiązków. Najlepiej, jak zalecano, by wszelkie jej czynności przy dziecku były stale nadzorowane osobiście przez samą matkę. Przyjąwszy mamkę, matka nie powinna ani na chwilę zdawać dziecka na wytaczna jej opiekę $e^{59}$ - zalecano w jednym z poradników.

${ }^{55}$ Poradnik dla młodych matek, s. 118, 120; Jak zachować dziecko zdrowem?, s. 41; Jak pielęgnować dzieci zdrowe, s. 11; Higiena polska, t. 1, s. 33; Medycyna ludowa, s. 86; Rady dla młodych mężatek, s. 99.

${ }_{56}$ Poradnik dla mlodych matek, s. 119-120; Higiena polska, t. 1, s. 33-34, 113-114; Matka i dziecko, s. 79; Rady zachowania się niewiast czasu brzemienności, s. 236-239; Dyjetetyka dzieci, s. 19; Medycyna ludowa, s. 86.

${ }^{57}$ Poradnik dla mlodych matek, s. 108; Higiena polska, t. 1, s. 110.

58 Doc. dr J. Trumpp, op. cit., s. 231.

59 Wychowanie dziecka wedtug B.H. Gausserona, s. 15, 178; Poradnik dla młodych matek, s. 109; K. Nakwaska, Dwór wiejski: dzieło poświęcone gospodyniom polskim, przydatne i osobom w mieście mieszkajacym, t. 1, Lipsk 1857, s. 33; Chowanna, czyli system pedagogiki narodowej, s. 383; Dr E. Brucke, op. cit., s. 36. 
Do głównych obowiązków mamki, obok oczywiście karmienia piersią, należała całodobowa opieka i pielęgnacja oseska ${ }^{60}$. W nielicznych tylko domach rodzice zatrudniali jednocześnie mamkę dla karmienia i piastunkę do wykonywania pozostałych czynności pielęgnacyjnych. Mamka oczywiście wykonywać miała swe obowiązki pod opieką i kierunkiem troskliwej matki. Jej zadaniem było przewijanie niemowlęcia, ubieranie, usypianie, kąpanie, troska o czystość pokoju dziecinnego, wyprowadzanie dziecka na spacery, czuwanie nad jego bezpieczeństwem, pielęgnowanie w czasie choroby i zajmowanie zabawą. Nie bez powodu więc poszukiwano mamek, które już wcześniej karmiły dzieci, gdyż zdążyły już one nabrać wprawy i doświadczenia w zajmowaniu się nimi.

Jeśli mamką była kobieta wiejska, nawykła do codziennej pracy, to nie należało przesadnie zmieniać jej trybu życia (chyba, że była krótko po porodzie, wtedy powinna wypoczywać) - obok opieki nad dzieckiem mogła ona wykonywać pewne czynności porządkowe w domu pracodawców. Młode matki często odsuwały mamki od pracy, pozwalały na bezczynność, rozpieszczały, sądząc, że odbije się to korzystniej na mleku, a więc i na zdrowiu dziecka. Na stronach wielu poradników sugerowano, że mamka, obok opieki nad dzieckiem może spełniać dodatkowe obowiązki, np.: Kobieta wiejska, jaka zwykle bywa mamka, do czynności nawykła, jakże może czerstwość swa zachować w gnuśności i próżnowaniu? Trzeba więc, aby wszelka ustuga pokojowa przez mamkę czyniona była. Zamiatać, wycierać posadzki, sprzątać, słać łóżka niech będzie jej zatrud$n_{\text {nieniem }}{ }^{61}$. Niech mamka nosi drzewo $i$ wodę, niech pierze bieliznę dziecięca $i$ inne spetnia posługi ${ }^{62}$. Szczególnie podkreślanym w poradnikach higienicznych zadaniem mamki była troska o czystość dziecka i jego otoczenia, będąca warunkiem zdrowia. Miała ona dbać o czystość powietrza w pokoju dziecinnym, czystość bielizny i częstej jej zmiany, czystość naczyń do mycia, sprzętów i zabawek. Zadaniem mamki była też codzienna kąpiel i wieczorne mycie dziecka, pielęgnowanie włosów, oczu, nosa, ust, przyzwyczajanie dzieci do regularnego oddawania moczu (już od 3-4 miesiąca życia na leżąco nad naczyniem, kiedy dziecko siedziało, kilka razy dziennie należało sadzać je na nocnik). Mamka również miała troszczyć się o czystość własnego ciała i ubrań ${ }^{63}$.

Najemna karmicielka miała karmić dziecko do szóstego miesiąca życia tylko i wyłącznie swoim mlekiem (o ile mleko to służyło dziecku lub mamka wcześniej nie straciła pokarmu), wtedy to zwykle wyrzynały się niemowlęciu pierwsze ząbki, będące sygnałem, że do diety włączyć można i inne pokarmy. Podawać je należało obok mleka mamki, które z czasem, powoli należało zastępować innymi produktami, aż do całkowitego odstawienia piersi. Wśród osób formułujących porady nie było jednomyślności w kwestii, jak długo należało karmić dziecko piersią. Skrajne opinie oscylowały na kon-

${ }^{60}$ Do obowiązków mamki należy utrzymywanie porządku w pokoju dziecinnym, pranie bielizny dziecka i wszelkie postugi przy dziecku, w: Matka i dziecko, s. 80.

${ }^{61}$ K. Nakwaska, op. cit., t. I, s. 311-313; Poradnik dla młodych matek, s. 159; Jak zachować dziecko zdrowem?, s. 25, 27-28, 41-42; Matka i dziecko, s. 80-81; Dr Z. Taussig, op. cit., s. 31; A. Józefczyk, op. cit., s. 7.

${ }^{62}$ Rady dla młodych mężatek, s. 99-100.

${ }^{63}$ Matka i dziecko, s. 13-14; Dr E. Brucke, op. cit., s. 34; Dr A. Fischer-Dueckelmann, op. cit., s. 739-740; Rady zachowania się niewiast czasu brzemienności, s. 241; Rady dla młodych mężatek, s. 75, 101. 
tinuum od 6 miesięcy do 2 lat życia dziecka, z najczęstszym jednak wskazaniem, by odstawiać dziecko między 10 a 13 miesiącem. Do 2 lat zalecano karmić piersią dzieci chorowite, słabe, ze szczególną skłonnością do chorób skrofulicznych ${ }^{64}$. Najlepiej, by odstawianie od piersi odbywało się późną wiosną, kiedy mleko krowie było wysokiej jakości, pojawiały się świeże warzywa i owoce, a piękna pogoda pozwalała maluchom na częsty pobyt na powietrzu i zabawy oraz zajęcia odciągające i odwracające uwagę od piersi ${ }^{65}$. Oczywiste jest, że dłuższe karmienie przez mamkę narażało rodzinę ją zatrudniającą na ponoszenie kosztów jej utrzymania, a dziecko nie zawsze chciało przestać ssać. Dlatego też podawano sposoby, które matka mogła zlecić mamce do wykonania, by skutecznie obrzydzić dziecku pierś - zalecano np. smarowanie gorzkim wyciągiem z piołunu. Mamka dbać także powinna, by podczas odstawiania malucha, trwającego zwykle ok. czterech tygodni, nie narazić się na zastoje pokarmu, stany zapalne, owrzodzenia, a po ostatnim karmieniu, by wstrzymać wydzielanie mleka, miała obwiązać piersi (ale nie mocno uciskać), trzymać je w cieple, otulając watą, flanelą lub zamszem, smarować ogrzaną oliwą (najlepiej migdałową), niewiele jadać i od czasu do czasu brać leki na przeczyszczenie $^{66}$.

O fakcie, czy odżywanie przez mamkę było dla dziecka właściwe, świadczył brak dolegliwości, właściwy rozwój oraz dobre przybieranie na wadze. W poradnikach znajdujemy dokładne dane wagi dzieci karmionych piersią w poszczególnych tygodniach życia, tak, by każda matka mogła sprawdzić wartość odżywczą mleka karmicielki ${ }^{67}$. O dobrym przyswajaniu pokarmu świadczyło także regularne oddawanie przez dziecka moczu i tzw. stołeczków, które powinny być żółte i bez przykrego zapachu, brak wymiotów, ulewania, oraz długi i spokojny sen po karmieniu. Wskaźnikiem, że mleko mamki nie służyło dziecku, były stosunkowo często występujące u dzieci zaburzenia trawienia. Pojawiające się niestrawności, bóle brzucha, kolki, wymioty, rozwolnienia (dyarrye) czy zatwardzenia, o ile nie ustąpiły po zmianie diety przez karmiącą, sugerowały koniecz-

\footnotetext{
${ }^{64}$ Do chorób skrofulicznych w analizowanym okresie zaliczano: krzywicę (chorobę angielską), obrzęk gruczołów limfatycznych, skrofuliczne zapalenia oczu, skóry, stany zapalne w kościach, garb, za: Skrofuły (zołzy), s. 10-11; Zob. też: Choroby kobiece, s. 6-7; Rady dla matek, s. 20, 42-43; Upominek dla matek, s. 11; Higiena polska, t. 1, s. 36; Matka i dziecko, s. 115-116, 217-218; Dr E. Brucke, op. cit., s.12, 37; Dr med. M. Biehler, Podręcznik higieny, s. 152-153; Dr A. Fischer-Dueckelmann, op. cit., s. 47, 757-758; Dr M. Biehler, Higiena dziecka, s. 125-126; Dr Z. Taussig, op. cit., s. 71-77; Żeby nie chorować, s. 188; Medycyna ludowa, s. 86

${ }^{65}$ Poradnik dla młodych matek, s. 181-183; K. Nakwaska, op. cit., t. I, s. 313; Jak zachować dziecko zdrowem?, s. 45, 57; O budowie i pielegnowaniu ciała ludzkiego, s. 214-215; Dr A. Fischer-Dueckelmann, op. cit., s. 757-758; Leki domowe zastosowane w chorobach ludzkich, zebrał dr E. Krzyżanowski, Warszawa 1901, s. 159; Praktyczny przewodnik wychowania, s. 16.

${ }^{66}$ Poradnik dla młodych matek, s. 151-1553, 183-185; Jak zachować dziecko zdrowem?, s. 59; Higiena polska, t. 1, s. 37; O budowie i pielęgnowaniu ciała ludzkiego, s. 214; Matka i dziecko, s. 82, 115; Dr W. Hojnacki, op. cit., s. 371; Dr med. S. Breyer, op. cit., s. 37; Domowy poradnik lekarski, s. 23; O wychowaniu macierzyńskim, s. 19; Podręcznik do leczenia chorób, s. 309; Rady dla młodych mężatek, s. 129.

${ }^{67}$ Zob. np.: Jak zachować dziecko zdrowem?, s. 43-44; Choroby kobiece, s. 5; Matka i dziecko, s. 82, 207; Dr E. Brucke, op. cit., s. 6-8; Dr med. M. Biehler, Podręcznik higieny, s. 151-152; Dr med. S. Breyer, op. cit., s. 34-35; M. Biehler, Higiena dziecka, s. 64-65, 123; Dr Z. Taussig, op. cit., s. 22-24; Doc. dr O. Schaeffer, op. cit., s. 182, 193; Dr med. L. Natanson, op. cit., s. 151
} 
ność zmiany karmicielki lub zmianę pokarmu na sztuczny. Najlepiej było, by raz wybrana mamka karmiła oseska do chwili odstawienia, jednak kiedy jej mleko wyraźnie mu szkodziło, zalecano ją zmienić, szczególnie, kiedy dziecko nie zdążyło się jeszcze do niej przywiązać. Jeśli choroba $w$ dziecku wyśledzić się nie da, trzeba zmienić sposób życia karmiącej, gdy i to nie wystarcza, trzeba zmienić karmicielkę - na pewno się uspokoi ${ }^{68}$.

W społeczeństwie badanego okresu panował pogląd, że dziecko wraz z mlekiem matki wysysało określone cechy osobowości, pewne jej przywary, wady, ale też zalety. Liczne naokoło nas żyja familie, które zaprzeczyć nie moga, iż ich dzieci nie tylko chorobami ciała, ale i nadto wadami czysto duchowymi mamek, które je karmity, zarażone zostały ${ }^{69}$. Autorzy poradników, powołując się na wyniki badań swoich i innych lekarzy, podawali liczne przykłady wpływu mleka matki na karmione dzieci - nie tylko w sferze fizycznej, ale i duchowej. I choć asekurowano się stwierdzeniem, że nie jest do końca wiarygodne, aby namiętności i charakter mamki przez samo tylko mleko udzielać się miały ssącym niemowlętom, to z drugiej strony całkiem tego wpływu zaprzeczyć mleku kobiecemu jest rzecza niepodobna, gdy nie zbywa bynajmniej na przykładach, które o nim świadczą ${ }^{70}$. Nie bez powodu używano często powiedzenia ,wyssane z mlekiem matki” - rozumiejąc przez to duchowe przymioty człowieka ${ }^{71}$. W połowie XIX w. Teodor Tripplin podkreślał konsekwencje karmienia przez mamkę dla rozwoju charakteru dziecka: $Z$ samym mlekiem przechodza z mamki do dziecięcia złe skłonności, które potem, zwłaszcza przy naszym niesprężystym postępowaniu $w$ wychowaniu bardzo łatwo wybujać moga $w$ wady charakteru najnieznośniejsze. Poglądy te prezentowała większość piszących wskazówki dla matek przez cały badany okres. Jeszcze w początku wieku XX, w poradniku lecznictwa przyrodnego czytamy: Razem z mlekiem mamki musza się także wszystkie namiętności i skłonności mamki na dziecko przenieść, tj. dziecko wsało z mlekiem mamki skłonność do kłamstwa, do gniewu, do lenistwa itp. ${ }^{72}$

W domu pracodawców mamkę należało odpowiednio traktować. Skoro ,pani” sama nie karmiła piersią, wszelkie porady dotyczące karmiącej, formułowane na stronach poradników, przechodziły na karmiącą mamkę. Traktując dobrze mamkę i dbając o nią, matka dbała jednocześnie o dobro i zdrowie swojego dziecka. Powinna ona dbać o mamkę tak, jakby troszczyła się o siebie, gdyby karmiła. Zadaniem więc matki było czuwać, by zdrowie i samopoczucie mamki były jak najlepsze, co gwarantowało korzyści dla dziecka nie tylko w jakości mleka, ale i w jakości opieki i pielęgnacji.

Należało zapewnić mamce odpowiednie warunki bytowania - Karolina Nakwaska w połowie wieku XIX radziła np. matkom, urządzającym ziemiańskie dwory, dać mamce

${ }^{68}$ Rady dla matek, s. 34; Poradnik dla młodych matek, s. 192-193; Jak zachować dziecko zdrowem?, s. 45; Dr A. Fischer-Dueckelmann, s. 733; Dr Z. Taussig, s. 21-30; Doc. Dr O. Schaeffer, s. 192; Rady dla młodych mężatek, s. 79.

69 Poradnik dla mlodych matek, s. 27.

${ }^{70}$ Ibidem, s. 74-75; Higiena polska, t. 1, s. 109; F. E. Bilz, op. cit., s. 381; Dyjetetyka dzieci, s. 15; Ks. S. Kneipp, Dziecko zdrowe i chore, s. 36; Szkice pedagogiczne, s. 74; Domowa pomoc, s. 93.

${ }^{71}$ F. Lotzky, s. 16, w: Higiena polska, t. 1, s. 109; Zob. też: Szkice pedagogiczne, s. 75; Poradnik dla młodych matek, s. 27; Matka i dziecko, s. 80; O wychowaniu macierzyńskim, s. 16.

${ }^{72}$ F. E. Bilz, op. cit., s. 381. 
do dyspozycji nie tylko osobne, wygodne i ciepłe łóżko w pokoju dziecinnym, ale odpowiednie sprzęty - szafkę nocną, komodę czy półkę, w której trzymała będzie swoje rzeczy, szafę na odzież, stolik ze sprzętami do mycia i innych czynności higienicznych. Dla wygody należało sprawić mamce niskie krzesełko do karmienia. Dobrze było sprezentować kobiecie zwierciadło, szczotkę, grzebień, chustki do nosa, ręczniki, fartuszki. Nie odmawiaj osobnego miejsca na rzeczy bony czy mamki, inaczej jej graty wszędzie na przeszkodzie Ci będq ${ }^{73}$ - pisała. Podobne zalecenia formułowano również w innych poradnikach badanego okresu ${ }^{74}$.

By mleko mamki było zdrowym dla karmionego niemowlęcia, powinna się ona odpowiednio odżywiać. Świadomość, że pokarm, jaki spożywa służy nie tylko jej samej, ale szczególnie wzrostowi i rozwojowi dziecka miała powodować, by mamka spożywała posiłki pożywne, we właściwych ilościach, odpowiedniej jakości, o odpowiednich porach, by dbała o dobry apetyt. Nie wolno jej było nadwyrężać żołądka, doprowadzać do zaburzeń trawiennych, zaś szczególnie niekorzystne było spożywanie napojów alkoholowych, które przenikały do pokarmu i szkodziły dziecku. Zalecano, by mamka piła napar z dziewanny z mlekiem lub odwar z kopru, które nie powodowały u dziecka wzdęć. Podawano także cały repertuar pokarmów, których mamka nie powinna spożywać, by nie zaszkodzić karmionemu niemowlęciu. Wskazywano tu na surowe owoce, np. agrest, jabłka, gruszki, śliwki, wiśnie, niektóre warzywa: kapusta, cebula, czosnek, groch, rzodkiew, szczaw, ogórki, szparagi, mięsa: świńskie, gęsie, kacze, szczególnie thuste i wędzone, kiełbasy, ryby, grzyby, przyprawy korzenne, ciasta francuskie itp. Zalecano natomiast wszelkie buliony, rosołki, mleko, maślankę, słabą herbatę lub kawę z mlekiem, wodę, biały chleb, masło, jaja, jarzyny nierozdymające, białe mięso ptactwa, sarninę, wołowinę, cielęcinę, zająca, konfitury, owoce suszone, gotowane lub pieczone, różnego rodzaju kasze. Jeśli jednak mamka pochodziła ze wsi, zalecano zapytać ją o dotychczasowy sposób odżywania i nie odstępować od niego zbytnio. Uświadamiano matkom, że nie ma pokarmów, które jak powszechnie uważano pomnażają ilość mleka w piersiach (np. zupki, kleiki, wodzianki, pokarmy płynne) i że nie należy zmuszać mamek do spożywania pokarmów, do których nie przywykły i które im nie smakują, bez jednak przesadnego znoszenia kaprysów w tej kwestii ${ }^{75}$.

${ }^{3}$ K. Nakwaska, op. cit., t. I, s. 34, 50-52, 197, 310

${ }^{74}$ Mamka powinna sypiać w cieplym łóżku, w dobrze wywietrzonym pokoju i mieć możność dobrego mycia się, w: Matka i dziecko, s. 80; Zob. też: Rady zachowania się niewiast czasu brzemienności, s. 239.

75 Przykładowy jadłospis dla karmiącej mamki (miał być ułożony przez lekarza, by mamka nie mogła go poważyć i odmówić spożywania wskazanych produktów): Rano 3/4 kwarty mleka, butke z mastem, o 10-tej godz. dwa jajka, chleb z masłem, lekkie piwo, o 1-szej obiad złożony z zupy mlecznej lub macznej, kasza owsiana lub jęczmienna, mięso, kartofle (ale nie rozdymajace jarzyny) i owoce gotowane. O 4-tej 3/4 kwarty mleka, chleb z masłem, wieczorem jaja i piwo. Kawy i herbaty lepiej nie dawać, w: Matka i dziecko, s. 83; Zob. też: Poradnik dla młodych matek, s. 26, 144-145, 154, 157-158; K. Nakwaska, op. cit., t. I, s. 315-316; Jak zachować dziecko zdrowem?, s. 25-27, 42-43; Higiena polska, t. 1, s. 34; O budowie i pielęgnowaniu ciała ludzkiego, s. 215; Matka i dziecko, s. 81; Dr E. Brucke, op. cit., s. 9-10, 33-34; Dr W. Hojnacki, op. cit., s. 373-374; Dr A. Fischer-Dueckelmann, op. cit., s. 722, 739; F. E. Bilz, op. cit., s. 378, s. 379; Rady zachowania się niewiast czasu brzemienności, s. 240, 242; Domowy poradnik lekarski, s. 19; M. Biehler, Higiena dziecka, s. 120-121; Dr Z. Taussig, op. cit., s. 31; Dyjetetyka dzieci, s. 22; Doc. dr J. Trumpp, op. cit., s. 231; Leki domowe, s. 158-159; Rady dla młodych mężatek, s. 71-73. 
Spokój ducha karmiącej mamki był gwarantem dobrego mleka i spokoju dziecka. Dlatego też radzono, by troszczyć się o dobre samopoczucie mamki. Szczególnie niekorzystny wpływ na zdrowie i usposobienie dziecka miało mieć karmienie przez mamkę niespokojną, zmartwioną, zagniewaną, nerwową. Nie brakowało w poradnikach przykładów, iż wstrząsy emocjonalne u mamki, gwałtowne poruszenia, silny gniew, przestrach powodować mogły u niemowlęcia rozwolnienie, kolki, wymioty, gorączkę, rozdrażnienie, konwulsje. Przytaczano także przypadki tknięcia dzieci paraliżem czy napadami epilepsji, a nawet śmierci. Należało pilnować, by we wskazanych wypadkach mamka ściągnęła pokarm, który mógł niekorzystnie, a nawet tragicznie wpłynąć na dziecko. By zachować mamkę w dobrym zdrowiu psychicznym i fizycznym, radzono, by regularnie odpoczywała ona od codziennych obowiązków, korzystała ze spacerów i świeżego powietrza. Ruch fizyczny wpływać miał bowiem na obfitość mleka, dlatego należało go regularnie zażywać, a dodatkowo nie dopuszczat nudów, trosk urojonych i zgubnych obrazów wyobraźni, utrzymując umyst w ciagtym zajęciu i równowadze ${ }^{76}$. Przynajmniej godzina zatrudnienia na powietrzu i przechadzka mogły zostać połączone ze spacerem także dla dziecka. Należało jednak pilnować, by na spacery z dzieckiem mamka wychodziła w towarzystwie zaufanej osoby, kontrolującej, z kim ta się spotyka, i pilnującej, by spacer, zamiast w parku, nie kończył się u koleżanki czy w innym miejscu. Jeżeli mamka sama tylko z dzieckiem, które wiezie $w$ wózeczku, a w drodze się z kim spotka i stanie do pogadanki [...], a dziecko placzem zmusza do przerwania najinteresowniejszej pogadan$k i$, wtenczas przekleństwa sypia się bez miary, a i o uderzenia nie skapo, bo dziecko się pożalić nie potrafi. A najgorsza jest, co także nieraz się wydarza, jeżeli spotka się z swoim wielbicielem, który zaprowadzi do szynku $u^{77}$ - przestrzegał matki autor jednego z poradników. Towarzystwo miało więc także uchronić mamkę przed niebezpieczeństwami zepsucia, czyhającymi na nią podczas samotnych przechadzek. Mamka nie powinna także chodzić na dalekie piesze wycieczki, tańce, oraz jeździć konno ${ }^{78}$.

Zadaniem matki było także troszczyć się o zdrowie karmiącej matki. Obok właściwego odżywania, winna matka także sprawdzać, czy mamka nie nabawiała się jakiejś choroby, która może niekorzystnie wpływać na dziecko. Szczególnie należało unikać przeziębienia, niestrawności, nerwowości. Należało przyzwyczaić mamkę, by komunikowała matce wszystkie zmiany w swoim zdrowiu - ukrywana choroba często była bowiem przyczyną choroby dziecka. Zalecano nawet, by matka sprawdzała odchody naturalne mamki, reagując natychmiast $\mathrm{w}$ wypadku rozwolnienia, zatwardzenia, pojawienia się miesiączki (mamki często ten fakt ukrywały, obawiając się zwolnienia, lecz zwykle nie wpływało to negatywnie na stan zdrowia dziecka). Mamka powinna raz dziennie odda-

76 Ibidem, s. 73-74.

77 A. Józefczyk, op. cit., s. 21.

${ }^{78}$ K. Nakwaska, op. cit., t. I, s. 311-313; Poradnik dla młodych matek, s. 159; Jak zachować dziecko zdrowem?, s. 25, 27-28, 41-42; Matka i dziecko, s. 81; Dr E. Brucke, op. cit., s. 34; Dr W. Hojnacki, op. cit., s. 374; Dr med. S. Breyer, op. cit., s. 31; Rady zachowania się niewiast czasu brzemienności, s. 239; M. Biehler, Higiena dziecka, s. 121, 199; Dr Z. Taussig, op. cit., s. 31; Dyjetetyka dzieci, s. 19-20; Doc. dr J. Trumpp, op. cit., s. 231; Dr med. L. Natanson, op. cit., s. 150; Leki domowe, s. 159; Rady dla młodych mężatek, s. 73-75; Domowa pomoc, s. 93. 
wać stolec, którego nie wolno było wywoływać środkami przeczyszczającymi, ale piciem wody, ruchem fizycznym, ewentualnie lewatywą. Matka zakazać powinna mamce jakichkolwiek kontaktów seksualnych z mężczyznami (spotkania mamki zamężnej z mężem odbywać się miały wyłącznie pod okiem matki dziecka), gdyż te mogły doprowadzić do kolejnej ciąży i konieczności przerwania karmienia. Kiedy mamka czuła się źle, nie należało leczyć jej samodzielnie, domowymi sposobami, lecz od razu należało radzić się lekarza, który powinien zdecydować o kontynuacji lub zaprzestaniu karmienia. Od niego też zależało, jakie leki otrzyma karmiąca, by nie wywarły one szkodliwego wpływu na dziecko. W wypadku zarażenia się chorobą zakaźną, np. płonicą, tyfusem, ospą, cholerą, natychmiast należało dziecko odstawić ${ }^{79}$.

W poradnikach znajdujemy też opisy strojów kobiet karmiących - mamka powinna ubierać się w odzież w miarę możliwości jak najwygodniejszą, z łatwym dostępem do piersi, nieuciskającą. W czasie chłodnych miesięcy należało chronić piersi oraz stopy przed zaziębieniem, gdyż nawet najmniejsze wychłodzenie powodować miało zmniejszenie ilości pokarmu, a poważniejsza infekcja powodowała całkowitą jego utratę oraz zapalenie gruczołów mlecznych ${ }^{80}$.

Mamka, od której autorzy poradników wymagali wielu przymiotów duszy i ciała musiała być odpowiednio w domu pracodawcy traktowana i wynagradzana. Z racji opieki nad dzieckiem państwa należały się jej wspomniane już właściwe warunki bytowania, a więc miejsce do spania, odpowiednie pożywienie, zaufanie i sympatia ze strony domowników. Również pensja powinna być na tyle wysoka, by wystarczyło jej na opłacenie opieki nad własnym dzieckiem i zaspokojenie innych potrzeb, a wypłacać ją należało regularnie i zgodnie z zawartą wcześniej umową - miesięcznie, czy kwartalnie. Przy różnorakich okazjach można było dawać mamce drobne podarunki - najczęściej przedmioty osobiste codziennego użytku, zaś przy wyjątkowych okazjach np. książeczkę do nabożeństwa, krzyżyk czy medalik, zegarek, monetę z wizerunkiem Matki Boskiej. Prezenty takie miały mamce okazać szacunek i wdzięczność za dobrze wykonywane obowiązki i rodzić przywiązanie do pracodawców ${ }^{81}$.

Mamka zwykle przebywała w domu swoich pracodawców na czas karmienia powierzonego sobie dziecka, ale mogło się zdarzyć, że zostawała przy rodzinie na dłużej. Radzono, by dobrze wykonującą swoje obowiązki mamkę zatrzymać i zatrudnić jako piastunkę do dzieci, względnie, jeśli wyrazi chęć dalszej pracy w danej rodzinie - jako kucharkę, praczkę lub gospodynię. Sugerowano, że przebywawszy jakiś czas przy rodzinie, nie tylko przywiązuje się do dziecka i otoczenia, ale i uczy się zwyczajów panują-

${ }^{79}$ Poradnik dla młodych matek, s. 161; Higiena polska, t. 1, s. 35; Matka i dziecko, s. 82; Dr W. Hojnacki, op. cit., s. 374; Dr A. Fischer-Dueckelmann, op. cit., s. 740; Rady zachowania się niewiast czasu brzemienności, s. 245; Dr Z. Taussig, op. cit., s. 1-17; Dyjetetyka dzieci, s. 20; Doc. dr O. Schaeffer, op. cit., s. 194; Doc. dr J. Trumpp, op. cit., s. 227; Medycyna ludowa, s. 86; Rady dla młodych mężatek, s. 69; Domowa pomoc, op. cit., s. 92 .

${ }^{80}$ Jak zachować dziecko zdrowem?, s. 28.

${ }^{81}$ Przykładowe kwoty wynagrodzenia zob. np.: Poradnik dla młodych matek, s. 120-121; K. Nakwaska, op. cit., t. I, s. 197, 199; Przy kądzieli. Pogadanki dla kobiet o ważnych sprawach, napisała Antoszka, Warszawa 1913 , s. 58-59; Dyjetetyka dzieci, s. 19. 
cych w domu, zna zakres obowiązków pozostałych ze służby i powinna spełnić się w którejś ze wskazanych ról. Sytuacja, kiedy mamka zostawała dalej niańką dziecka, miała być korzystną także dla podopiecznego. Wcześniej przyzwyczaił się on do niej, więc jej odejście nie będzie wiązało się z rozłąką i z tęsknotą za bliską osobą ${ }^{82}$.

Nie zawsze współpraca rodziców, a szczególnie matki z mamką układała się pomyślnie. Kiedy mamka okazywała się opieszałą w wykonywaniu obowiązków, leniwą i kapryśną, często czyniono błąd - zmieniano karmicielkę. Teodor Tripplin opisywał przypadek dziecka możnych i światłych rodziców, które w czasie siedmiu miesięcy miało trzynaście mamek i w końcu zmarło ${ }^{83}$. Mamki, przy której dziecko pomyślnie się rozwija, nie powinni rodzice odprawiać aż do zupetnego odłaczenia dziecka o piersi. Niechby sobie była wymagajaca, impertynencka, niechby nawet kradła, wszystko to jest niczym w porównaniu z niebezpieczeństwem, na jakie wystawia się dziecko przez zmiane mam$k i^{84}$, czytamy w jednym z poradników. Wśród powodów, dla których należało zmienić mamkę wskazywano: zniechęcenie lub obojętność do powierzonego jej niemowlęcia, nałóg obżarstwa lub opilstwa, niemoralne prowadzenie się. Nieporozumienia, niechęć wobec pracodawców, karmionego dziecka, brak związku emocjonalnego, przestrach, powodować mogły nie rzadko zdarzające się sytuacje (jak podawały poradniki medyczne), że mamka, nawet mająca duże ilości mleka, w ciągu dziewięciu dni zupełnie traciła po$\mathrm{karm}^{85}$. O zatrudnieniu kolejnej mamki powinien zawsze decydować lekarz, który mógł również zlecić karmienie sztuczne. Decyzja zależeć miała od wieku dziecka, jego stanu zdrowia, pory roku ${ }^{86}$.

Radząc rodzicom, jak obchodzić się mamką uświadamiano, że istnieje tyle sposobów współpracy, ile charakterów ludzkich. Zatrudniając mamkę należało dobrze ją poznać i do jej usposobienia, osobowości i zachowania dostosować sposób traktowania. Z racji jednak stanu i pochodzenia zawsze należało pamiętać, że to mamka jest służącą, a matka osobą decydującą i nie matka mamce, a mamka matce powinna być posłuszną. Jak bowiem twierdzono, bywało i tak, że matki, pragnąc dobra swego dziecka z pokorą zanosiły kaprysy i zachcianki mamek, które, chcąc zyskać dla siebie ustępstwa i przywileje, groziły rodzicom porzuceniem służby. Zatrudniając karmicielkę, dobrze było zaraz po jej przyjęciu do domu dokładnie omówić zakres jej obowiązków i zadań, które podejmować miała obok karmienia dziecka. Obok obowiązków wynikających z pracy, należało także wyraźnie określić swoje wymagania co do moralności i sposobu prowadzenia się mamki oraz bezwzględnie zakazać jej wszelkiego zgorszenia i pijaństwa. Ogólnie rzecz biorąc, należy mamkę utrzymać w szczęściu, rozkoszy i swobodzie, ale równocześnie $w$ zależności, jaka z natury powołania wynika ${ }^{87}$. Dlatego też zalecano, by zachować odpowiedni

${ }^{82}$ K. Nakwaska, op. cit., t. I, s. 190-191; O wychowaniu macierzyńskim, s. 18.

${ }^{83}$ Higiena polska, s. 110; Matka i dziecko, s. 79-80, s. 80; Dr Z. Taussig, op. cit., s. 40.

${ }^{84}$ Dr E. Brucke, op. cit., s. 34.

${ }^{85}$ Poradnik dla młodych matek, s.21; Dyjetetyka dzieci, s. 23.

${ }^{86}$ Dr E. Brucke, op. cit., s. 36; Dr A. Fischer-Dueckelmann, op. cit., s. 752.

${ }^{87}$ Poradnik dla mlodych matek, s. 161; Matka i dziecko, s. 80; Rady zachowania się niewiast czasu brzemienności, s. 246; Dr Z. Taussig, op. cit., s. 32; Doc. dr J. Trumpp, op. cit., s. 230-231. 
dystans, nie spoufalać się z piastunką, nie pobłażać jej lekkomyślności, bezwzględnie żądać zachowania zgodnego z zaleceniami. Jednocześnie sugerowano, by matka nie była zbyt sroga wobec karmicielki, by za dobre pełnienie obowiązków chwaliła, nagradzała drobnym podarunkiem. Karanie czy łajanie służącej miało być wynikiem rzeczywistego jej przewinienia, nie zaś złego humoru czy gniewu pracodawczyni. Uświadamiano rodzicom, że mamka także powinna mieć możliwość rozrywki, spędzenia czasu wolnego w dowolny sposób, bez poczucia ciągłego dozoru. Dobrze, by matka zadbała o to, by służba w domu z należytym szacunkiem traktowała mamkę $e^{88}$.

Jak wynika z analizowanych pozycji poradnikowych, mamki, mimo swej popularności, nie cieszyły się dobrą opinią społeczeństwa i autorów poradników. Twierdzono powszechnie, że kobiety, które za pieniądze wynajmowały się do karmienia obcych dzieci traktowały swoją pracę jako interes i nie rozumiały często odpowiedzialności, jaką na siebie brały ${ }^{89}$. Sa to $w$ naszych warunkach kobiety zupetnie ciemne, których nauki szczepia fatszywe idee i często wady charakteru. Otrzymuja od matki pewne wskazówki, co do positku, zachowania się i zabawy. Wskazówek tych najczęściej trzymać się nie lubia, ze szkoda fizyczna dla dziecka, często i molarna, gdyż malec otrzymuje przy tej sposobności pierwsza nauke kłamstwa i oszustwa. Braki pedagogicznego i moralnego wykształcenia tych pierwszych dozorczyń czynia dziecku krzywdę znaczną ${ }^{90}$. Nie brakowało więc w poradnikach przestróg, dotyczących błędów w opiece i pielęgnacji dziecka popełnianych przez mamki. Mogły one wynikać z ich niekompetencji czy braku wiedzy, jednak często były wynikiem braku kontroli ze strony matki i chęci ułatwienia sobie pracy ze strony mamki. Bardzo rzadko trafia się na mamke, któryby odpowiadała wszystkim wymaganiom i który by pokarm nadawat się $w$ zupetności dla dziecka. Dlatego też przy pierwszych wystepach mamki dziecko ma zazwyczaj niedyspozycje żoładkowo-kiszkowe; znacznie więcej ono jednak cierpi na skutek złych przyzwyczajeń i błędnych pogladów mamki na higienę dziecka ${ }^{91}$. Mamki sa zwykle przesadnie zabobonne i nieraz maja najdziwaczniejsze pojęcia o pielęgnowaniu dzieci ${ }^{92}$. Wobec tego typu zarzutów w części poradników adresowanych do matek wskazywano na rozliczne błędy popełniane przez mamki podczas wypełniania swoich obowiązków względem dziecka.

Należało pilnować, by mamki nie sypiały z powierzonymi sobie dziećmi w jednym łóżku. Czyniły tak często z wygody, by nie wstawać w nocy do kwilącego niemowlęcia.

${ }^{88}$ Poradnik dla młodych matek, s. 163; K. Nakwaska, op. cit., t. I, s. 194-196; Dyjetetyka dzieci, s. 19; Rady dla młodych mężatek, s. 103-104.

${ }^{89}$ Mamki patrza na karmienie, jako coś, co je wyciaga z nędzy i przynosi materialne korzyści, w: M. Biehler, Higiena dziecka, s. 121.

${ }_{90}$ Matka i dziecko, s. 217; Zob. też: Przesądy w wychowaniu. Studium pedagogiczne przez Waleryę Marrene, Wilno 1881, s. 16.

91 Doc. dr J. Trumpp, op. cit., s. 230; Ksawery Pałuczanin podawał ku przestrodze matek przypadek mamki, która udusiła pięcioro kolejnych powierzonych jej noworodków, uzasadniając zbrodnie faktem, że nie mogła znieść ich krzyku - a chociażby opisany powyżej potwór mamki byt jedynym w swoim rodzaju, to już powinien on wystarczyć do odstraszenia matek od powierzania dzieci swych najemnym karmicielkom, w: Szkice pedagogiczne, s. 75-76.

${ }_{92}$ Rady dla młodych mężatek, s. 102. 
Jednak skutkiem takiego ułatwienia opieki nad nim mogło być uduszenie. Jak podawano, częste były przypadki, że mamka, straciwszy podczas snu kontrolę nad ciałem, przyduszała dziecko swoim ciężarem i dusiła je. Nawet, gdy tak się nie działo, pisano, że wyziewy i pot mamki także mogły niekorzystnie wpływać na zdrowie ssawca ${ }^{93}$.

Za błędne uznawano reagowanie na każdy płacz dziecka przystawieniem go piersi. Takie postępowanie mamki powodowało u malca przejedzenie i dolegliwości trawienne. Zalecano karmić dziecko co kilka godzin, regularnie, najlepiej (szczególnie u starszych niemowląt) $z$ dłuższą nocną przerwą. Miało to przyzwyczaić dziecko do regularnych posiłków w ciągu dnia (najlepiej co trzy godziny), a z czasem z rezygnacji z karmienia nocą, zapobiegać dolegliwościom trawiennym, a także rozpieszczeniu dziecka. Dawało także mamce czas na odpoczynek i czynności inne, niż opieka i pielęgnacja powierzonego oseska ${ }^{94}$.

Upuszczenie dziecka przez mamkę było na tyle częstym wypadkiem, że w poradnikach zwracano uwagę, by noworodki i niemowlęta owijać w długie, wiązane na szarfy poduszki czy beciki, w których będą one noszone, gdyż w razie upadku amortyzują go, ratując dziecku zdrowie i życie. Taki becik, w który owijano dziecko chronił także przed tzw. przełamaniem (nie chodzi tu jednak o powijaki, których stosowanie odradzano, gdyż krępowały ruchy i swobodny rozwój członków dziecka) ${ }^{95}$. Szczególnie uwagę matek zwracano na zgubny nawyk kołysania dzieci do snu na ręku, dopóki nie zasnęły. Mamki czynić to miały, by rzekomo zapobiegać przepuklinie, powodowanej przez krzyk i długotrwały płacz dziecka. Noszenie i kołysanie („hocanie”) na rękach miało zapobiec płaczowi, a tym samym i chorobie. Uświadamiano matkom, że praktyki takie mają dwojaki negatywny skutek - moralny, bo przyzwyczajają dziecko do wymuszania płaczem noszenia i podporządkowywania sobie osób pielęgnujących, a także fizyczny - zasypianie na rękach powodować mogło skrzywienia kręgosłupa. Dzieci nauczone przez mamki zasypiania na rękach często nie chciały już sypiać w łóżeczku i budziły się przy każdej próbie odłożenia na posłanie. Krzyk zaś uznawano za naturalne ćwiczenie płuc, korzystnie wpływające na ich rozwój, przyspieszający krążenie krwi, niebędący przyczyną ani przepuklin, ani kurczów i nie zalecano go tłumić kołysaniem. Również odradzano kołysanie w kołysce ${ }^{96}$.

93 Poradnik dla młodych matek, s. 155, 159-160; Rodzina chrześcijańska, napisał O. Feliks Cozel T. J., Kraków 1908, s. 168; Matka i dziecko, s. 80; Dr E. Brucke, op. cit., s. 21; Nauka położnictwa, s. 36; Dr W. Hojnacki, op. cit., s. 374; Dr med. S. Breyer, op. cit., s. 33; Rady zachowania się niewiast czasu brzemienności, s. 246; Domowy poradnik lekarski, s. 15; Dr M. Biehler, Higiena dziecka, s. 127; O wychowaniu macierzyńskim, s. 16; Doc. dr O. Schaeffer, op. cit., s. 188; A. Józefczyk, op. cit., s. 7; Leki domowe, s. 62, 264.

${ }_{94}$ Rady dla matek, s. 19; O budowie i pielegnowaniu ciała ludzkiego, s. 214; Dr E. Brucke, op. cit., s. 4-7; Dr Z. Taussig, op. cit., s. 108; O wychowaniu macierzyńskim, s. 16-17; Ks. S. Kneipp, Dziecko zdrowe i chore, s. 33; A, Józefczyk, op. cit., s. 8; Poradnik dla młodych matek, s. 159, 169-170; Dr E. Brucke, op. cit., s. 4-7; Dr M. Biehler, Higiena dziecka, s. 123; Dr Z. Taussig, op. cit., s. 32; Ks. S. Kneipp, Dziecko zdrowe i chore, s. 33; Dr med. L. Natanson, op. cit., s. 149; Nasz dom, s. 292.

${ }_{95}$ K. Nakwaska, op. cit., t. I, s. 309-310; Rady dla matek, s. 85; Dr A. Fischer-Dueckelmann, op. cit., s. 735, 760-761; Dr med. L. Natanson, op. cit., s. 150; Rady dla młodych mężatek, s. 99.

96 Poradnik dla młodych matek, s. 216; Jak zachować dziecko zdrowem?, s. 31-32; Skrofuty (zolzy), s. 37; Rady dla matek, s. 34; Jak pielęgnować dzieci zdrowe, s. 9; Dobre i złe wychowanie dzieci w przykładach 
Niebezpieczne dla kręgosłupów dzieci było często praktykowane przez mamki przedwczesne sadzanie lub stawianie na nóżki, podtrzymywanie stawiającego pierwsze kroki malucha paskami, taśmami, ręcznikami, koszykami (które dodatkowo uciskały klatkę piersiową). Opisywano nawet przypadki wykręcania czy wyrwania rączek ze stawów podczas prób chodzenia. Również noszenie dziecka na jednym tylko, stale tym samym ręku miało być przyczyną skrzywień kręgosłupa czy garbów. Sugerowano także, by matka sprawdzała, dokąd mamka zabiera dziecko na spacer we wózku, gdyż jazda po drogach wyboistych czy nierównych powodować mogła u dziecka wstrząsy, w najgorszym wypadku wypadnięcie, potłuczenie, a nawet śmierć ${ }^{97}$.

Zwracano uwagę na fakt, że mamki często zapominały o obmyciu piersi po każdym karmieniu lub pozwalały dziecku zasypiać przy piersi, nie wymywszy im potem ust, co prowadziło bardzo często do powstawania pleśniawek - białych nalotów, które rozprzestrzeniały się na całą jamę ustną, gardło, powodowały ból przy ssaniu, niepokój u dziecka, słabsze przybieranie na wadze. By temu zapobiec matka miała pilnować, by mamka myła piersi po karmieniu i czyściła usta dziecka wodą, najlepiej z dodatkiem wody wapiennej ${ }^{98}$. Kiedy dziecko już dokarmiano i obok piersi otrzymywało ono inne pokarmy, mamki miały mieć zwyczaj oblizywania łyżki, którą karmiły dziecko - groziło to przeniesieniem zarazków i zarażeniem dziecka rozlicznymi dolegliwościami - zajadami w kącikach ust, wysypkami na wargach, katarem ${ }^{99}$.

Autorzy poradników krytykowali szczególnie przez mamki wiejskie stosowany zwyczaj usypiania dzieci, polegający na podawaniu im do ssania miazgi z ziaren maku zawiniętej w kawałek płótna (makówki), czy smoczek lub gałganek moczony w wódce ${ }^{100}$. Niektóre mamki, chcąc szybciej uśpić malca i zapewnić sobie spokojną noc piły alkohol, który przenikał do pokarmu i oddziaływał na dziecko. Jeśli dziecko śpi niezwykle dtugo, wówczas możemy przypuszczać, że mamka lub niańka dała mu coś na sen. Zdarza się to niestety dość często - dają albo środek apteczny, jak opium, lub wprost tyżeczkę słodkiej

podtug niemieckiego, opracowała I. Moszczeńska, Warszawa 1904, s. 3-6; Higiena polska, t. 1, s. 37-39; O budowie i pielęgnowaniu ciała ludzkiego, s. 217; Dr A. Fischer-Dueckelmann, op. cit., s. 772-774; $O$ wychowaniu macierzyńskim, s. 17, 20; Dyjetetyka dzieci, s. 21; Doc. dr J. Trumpp, op. cit., s. 207; Dr med. L. Natanson, op. cit., s. 157; Pedagogika polska, s. 59; Nasz dom, s. 292.

${ }_{97}$ Poradnik dla młodych matek, s. 235-236, 239-240; Jak zachować dziecko zdrowem?, s. 34-35; Rady dla matek, s. 35-37; Dobre i złe wychowanie, s. 16-17; Kodycyl do mojego testamentu dla zdrowych $i$ chorych, napisał Mgr. Sebastian Kneipp, przetłumaczył ks. J. A. Łukaszewicz, Kempten 1898, s. 84; Matka i dziecko, s. 96, 10-11, 215; Domowy poradnik lekarski, s. 29; Dr Z. Taussig, op. cit., s. 110-111; O wychowaniu macierzyńskim, s. 21-22; Dyjetetyka dzieci, s. 85-88.

98 Jak zachować dziecko zdrowem?, s. 58; Jak pielęgnować dzieci zdrowe, s. 13-14; Upominek dla matek, s. 14; O budowie i pielegnowaniu ciała ludzkiego, s. 214; Dr W. Hojnacki, op. cit., s. 373; Dr A. Fischer-Dueckelmann, op. cit., s. 495-496; Dyjetetyka dzieci, s. 23-24; Rady dla młodych mężatek, s. 148-149.

99 Upominek dla gospodyń, s. 10; Leki domowe, s. 159; Rady dla młodych mężatek, s. 129.

${ }_{100}$ Zdarza się, że dziecina okazuje pewien niepokój, kwili, prędko nie usypia - widocznie coś jej dolega. Mamka atoli niesumienna, albo zbyt leniwa, aby zbadać co dziecku potrzeba, w tajemnicy przed matka poi je odwarem z makówek, aby sama mogła spać spokojnie [...], w: C. Plater-Zyberkówna, s. 343; Jak pielęgnować dzieci zdrowe, s. 10; Rady dla matek, s. 25; Dr E. Brucke, op. cit., s. 11, 36; Dr med. M. Biehler, Podręcznik higieny, s. 451; Rady zachowania się niewiast czasu brzemienności, s. 245; Dr med. L. Natanson, op. cit., s. 157. 
wódki z odwarem koprowym ${ }^{101}$. Pisano także o podawaniu dzieciom przez mamki wody z domieszką koniaku, kirszu, a nawet wody kolońskiej. Takie postępowanie mogło po kilku latach powodować u tak karmionego dziecka wyrzuty skórne, spazmatyczne kurcze, nerwice opóźnienie umysłowe i inne choroby ${ }^{102}$. W wielu poradnikach przestrzegano matki przed innym, zgubnym dla dziecka sposobem usypiania przez mamki. Część z nich, chcąc szybciej uśpić niemowlę miała bowiem nacierać i masować okolice krzyża dziecka, łaskotaniem czy głaskaniem podrażniać jego narządy płciowe, co w konsekwencji mogło powodować u dziecka skłonność do masturbacji. Nie dozwalaj stużebnicy [...] usypiać dziecka. Ona jest zwykle zepsuta i łechce części wstydu, chcac wcześniej do snu zniewolić, a siebie uwolnić. Zaszczepi kakol złego $w$ dziecku i zabije $w$ nim zdrowie oraz moralność, jak to już niejednemu uczyniła ${ }^{103}$ - uświadamiano. Podawano także przykłady, iż mamki mogły być źródłem zakażeń dróg rodnych u dziewczynek, tzw. kataru zaraźliwego pochwy, który przenosić się mógł przez palce, bieliznę pościelową, ręczniki, gąbki ${ }^{104}$.

W nielicznych poradnikach (głównie o tematyce wychowawczej) wskazywano na znaczenie mamki dla rozwoju intelektualnego podopiecznego. Dziecko, jak uświadamiano rodzicom, zaczyna mówić około pierwszego roku życia. Najczęściej pierwsze proste słowa pochodzą $\mathrm{z}$ naśladownictwa zasłyszanych w najbliższym otoczeniu wyrazów, zwrotów, zdań. Należało więc także troszczyć o to, by mamka mówiła wyraźnie, czystym i prawidłowym językiem, gdyż dziecko słuchając jej słów, uczyło się mowy ${ }^{105}$. Nie powinna ona zmiękczać wyrazów, mówić gwarą, przeklinać, powinna zaś mieć „głos czysty i mowę niejąkającą" ${ }^{106}$. W Chowannie B. F. Trentowskiego znajdujemy wskazówkę, by piastunka wykorzystywała każdą sprzyjającą chwilę, by rozwijać u dziecka zasób pojęć. Zamiast je, jak to zwyczajem, na gwatt kołysać i do snu naglić, niechaj mu pokaże, zwłaszcza gdy niespokojne i płacze, zawsze coś nowego. Z początku dość jest na samym wskazaniu przedmiotu, później daj mu i przedmiot i nazwę. Nazwę tę wymieniaj śpiewajacym głosem, powtórz ja kilkakroć, aby tym pewniejsze uczyniła wrażenie. Tym sposobem wprowadzać będziesz każdy przedmiot w jednajże chwili do młodej wyobraźni [...] Wszelkie gospodarstwo domowe, czy wielkie, czy małe, ma mnóstwo przedmiotów, które

101 Matka i dziecko, s. 173.

${ }^{102}$ Ibidem, s. 81; Dr A. Combe pisał nawet o takim zjawisku, jak alkoholizm u ssawców, czyli dzieci karmionych piersią mamek, pijących alkohol, usypianych gałgankami czy smoczkami nasączanymi alkoholem, pojonych przed snem miksturami z alkoholem, w: Dr A. Combe, Nerwowość u dzieci. Cztery odczyty, przełożył i przypisami opatrzył dr H. Nusbaum, Warszawa 1904, s. 97-98; Ks. S. Kneipp, Dziecko zdrowe i chore, s. $33-34$.

${ }^{103}$ Chowanna, czyli system pedagogiki narodowej, s. 384; Marnopłcenie - onanizm (samogwalt, samienie się, nijactwo). Objawy, przyczyny, następstwa, zapobieganie, leczenie wedlug najnowszych postępów naukowych, pod red. A. Czarnowskiego, Berlin 1904, s. 29-30; Rady dla matek, s. 34-35; Dr E. Brucke, op. cit., s. 37; C. Plater-Zyberkówna, op. cit., s. 343.

104 Choroby kobiece, s. 9-10; O wychowaniu macierzyńskim, s. 21.

${ }_{105}$ Poradnik dla młodych matek, s. 244; Matka i dziecko, s. 86; Szkice pedagogiczne, s. 76-77.

106 Dyjetetyka dzieci, s. 19; Przesądy w wychowaniu, s. 16. 
dziecku z wolna i w pewnych czasach pokazywać można ${ }^{107}$. W końcu XIX w. formułowano poradę, by rozpoczynać mówienie do dziecka i pokazywanie mu najbliższego otoczenia już od ukończenia przez nie tzw. głupiego kwartału (oczywiście z umiarem, by nie przemęczać malca) ${ }^{108}$. Również śpiew mamki miał znaczenie dla rozwoju dziecka. Mamka niech śpiewa dziecku, ale niech nie pieje nad nim owym głosem fatszywym $i$ wytężonym, jak to u nas często czynia mamki wiejskie ${ }^{109}$ - powodować to miało u dziecka utratę słuchu, zdolności muzycznych i lękliwość.

Podsumowując powyższe ustalenia, należy podkreślić, że autorzy poradników mieli z pewnością świadomość, iż zamożne matki nie zrezygnują z przywileju najmowania karmicielek, nie tylko z powodu przyjętej mody, obyczaju stanowego i dobrej sytuacji materialnej pozwalającej na taką wyrękę, ale głównie ze względów ograniczania swobody życia przez opiekę nad niemowlęciem. Dlatego też formułowali szereg zaleceń, jak wybierać mamkę, by jej pokarm służył dziecku, powierzony jej osesek był bezpieczny, a matka była zadowolona ze współpracy z nią. Podkreślano, by wybór karmicielki uzależniony był od lekarza, a matka powinna nadzorować opiekę nad powierzonym niemowlęciem. Tryb życia karmiącej mamki powinien być higieniczny. Umiarkowana praca, wypoczynek, regularne odżywianie się, unikanie wszelkich wstrząsów fizycznych i spokój ducha stanowiły warunki zdrowia, dobrego samopoczucia, a tym samym dobrego pokarmu.

$\mathrm{Na}$ stronach poradników niezmiennie przez cały analizowany okres trwała szeroko zakrojona kampania na rzecz samodzielnego karmienia piersią przez matki. Jednak niemalejąca z upływem dziesięcioleci liczba porad i wskazówek dotyczących mamczarstwa, rozlicznych zaleceń dotyczących wyboru i powinności najemnych karmicielek sugeruje, że zatrudnianie mamek, mimo mijającego czasu, było niezmiennie palącym problemem społecznym, higienicznym, medycznym i moralnym. Zaangażowanie lekarzy, higienistów i pedagogów w formułowanie zasad żywienia piersią noworodków i niemowląt było znaczne, jednak krytykowane przez nich i często wytykane błędy w opiece i pielęgnacji niemowląt przez najemne karmicielki pozwalają przypuszczać, iż fachowe porady i zalecenia były często niespójne z zasadami praktykowanymi w rodzinach polskich badanego okresu.

Powyżej zaprezentowane ustalenia stanowią jedynie przyczynek do dalszych badań nad problematyką mamczarstwa na terenie ziem polskich doby zaborów. Warto zgłębić tę problematykę, z wykorzystaniem innych, bogatych materiałów źródłowych - ówczesnej prasy (szczególnie kobiecej i rodzinnej), kalendarzy, podręczników i poradników $\mathrm{z}$ różnych dziedzin, pamiętników i wspomnień, listów czy archiwaliów, a także materiałów ikonograficznych.

107 Chowanna, czyli system pedagogiki narodowej, s. 419; Jak zachować dziecko zdrowem?, s. 60; Rady dla matek, s. 98-99.

${ }^{108}$ Dr E. Brucke, op. cit., s. 23-24.

109 Higiena polska, t. 1, s. 38; Pogadanki i spostrzė̇enia z dziedziny fizjologii, psychologii, pedagogiki i nauk przyrodniczych przez Juliana Ochorowicza, Warszawa 1879, s. 91. 